\title{
Thomas Hobbes ve Leviathan'ı Üzerine Bir İnceleme: Yönetim Bilimi’ni İçeriye Almak
}

\author{
A Research on Thomas Hobbes and His Leviathan: Bringing the Administrative Science in
}

\author{
İbrahim Can KARADUMAN \\ Arş. Gör., Ankara Üniversitesi, $S B F$, \\ Siyaset Bilimi ve Kamu Yönetimi Bölümü, \\ icankaraduman@gmail.com \\ https://orcid.org/0000-0001-7302-5063
}

Makale Başvuru Tarihi: 11.02.2020
Makale Kabul Tarihi: 05.05.2020
Makale Türü: Araştırma Makalesi
Anahtar
Kelimeler:

Hobbes,

Leviathan,

Kamusal

Kuruluşlar,

Kamu Görevlileri,

Danışmanlık,

Keywords:

Hobbes,

Leviathan,

Public Institutions,

Public Officials,

Consultancy,

\section{ÖZET}

Siyaset Bilimi alanyazınında, Thomas Hobbes ve onun yazarlık veriminin doruk noktası olarak kabul gören Leviathan eseri üzerine, fazlaca çalı̧̧ma bulunmaktadir. Bu çalışmalarda genellikle; doğa durumu, doğa yasaları, devlet, egemenlik, meşruiyet, iktidar, otorite gibi kavramların üzerinde durulmakta ve Hobbes'un ortaya koyduğu devlet anlayışının olma/oluşturulma boyutu ile birlikte devletin kökeni derinlemesine ele alınmaktadır. Hobbes ve Leviathan eseri üzerine çalışma yapmak, şüphesiz Siyaset Bilimi'ne ilişkin kavram setlerini ele almayl gerektirmektedir. Ancak bu haliyle Hobbes'un Leviathan eserinde, sözleşme ile oluşturulan yapay bir insan olarak tanımladiğ devletin, işleyişine ve yönetimine ilişsin klsımlar eksik kalmaktadır. Dolayısıyla Hobbes'un Leviathan eseri üzerinden ortaya koyduğu devlet anlaylşını çalışmak; bir yandan devlet, egemenlik, meşruiyet, iktidar, otorite gibi kavramlar üzerinde durmayl gerektirirken, diğer yandan Yönetim Bilimi’ne ilişkin kamusal kuruluşlar, kamu görevlileri, yetki, sorumluluk, emir-tavsiye, danışmanlık gibi kavramlar üzerine bir okumayı da gerektirmektedir. Diğer bir deyişle Hobbes'un devlet anlayışı üzerine çalışmak, hem "olma" hem de "yapma" boyutlartyla eserde devletin oluşumunun ve işleyişinin temel ilkeleri üzerinde durmayı gerektirmektedir. Bu çalışmada, Hobbes'un devletin kökenine ilişkin getirdiği açılklamalar ile birlikte devletin varoluşsal nedeni ortaya konulmakta ve sonrasında, oluşturulan devletin işleyişine ilişkin kamusal kuruluşlar, devletin organları ve eklemleri olarak adlandırılan kamu görevlileri, bu organ ve eklemleri hareket ettiriciler olarak adlandırılan cezalar ve ödüller ile emir ve tavsiye sözcüklerinin analizi sonucunda çerçevesi çizilen danışmanlı olgusu ele alınmaktadır. Bunun nedeni, toplumsal sözleşme sonucu var edilen devletin işleyişinin hangi ilkelere göre kurgulandığını keşfetmektir. Çalışmada ayrıca, Hobbes'un hayatı ve yaşadı̆̆ı dönemin tarihsel koşulları da ele alınmaktadır. Buradaki amaç, düşünür ve eserine ilişkin bütüncül bir yaklaşım geliştirmektir.

\section{ABSTRACT}

There are many studies on Thomas Hobbes and his Leviathan work, which is well accepted as the culminating point of his authorship capacity, in the literature of Political Sciences. Generally in these studies, It is dwelt on the concepts such as state of nature, lex naturalis, the state, sovereignty, legitimacy, power, and authority, and the dimension of being/creating of the perceptive of the state which has been presented by Hobbes together with the origin of the state are discussed profoundly. There is no doubt that studying on Hobbes and Leviathan work requires to handle notion sets of Political Science. However, in this form, in the Leviathan work of Hobbes, the parts of the state's functioning and administration, which he defined as an artificial person created by the contract, are missing. Therefore, studying on the conception of the state that Hobbes has revealed via Leviathan work, on the one hand, requires to dwell on some notions like the state, sovereignty, legitimacy, power, and authority. On the other hand, it also requires to have a reading on the notions which are in relation to Administrative Science such as public institutions, public officials, authorization, liability, order-advice and consultancy. In other words, studying on Hobbes's conception of the state requires to deliberate over fundamental principles of the evolution and functioning of the state by means of both "being" and "doing" dimensions. In this study, Hobbes's statements about the origin of the state and existential reason of the state are revealed. In the sequel, public institutions which are related to functioning of the state, public officials which are denominated as organs and articulars of the state, punishments and awards which are named as driving forces for those organs and articulars, and phenomenon of the consultancy which is set the framework of itself as a result of analysis of order and advice, have been dealt with. The reason of this is to discover according to which principles the functioning of the state, which is created by social contract, is built. In this study, Hobbes's life and its historical conditions are also discussed. The aim here is to develop a holistic approach regarding the philosopher and his work. 


\section{GIRISS}

Bu çalışmada Thomas Hobbes'un (1588-1679) Leviathan (1651) eserinin, devlet bilimi açısından ne anlama geldiğinin ayrıntılarıyla ortaya konulması amaçlanmaktadır. Bu amaca uygun düşecek şekilde Leviathan eserinin incelenmesinin yanı sıra, Hobbes'un hayatı ve yaşadığ 1 tarihsel dönemin koşulları da incelenmektedir. Nitekim eserin yayımlandığı 17. yüzyıl, bilimsel devrim ve İngiltere'deki iç savaş ile politik devrimin gerçekleştiği bir yüzyıldır. Bu bakımdan birçok eser gibi Leviathan da, yayımlandığı döneminin koşullarından bağımsız olarak ele alınamayacak bir eserdir. Bunun yanı sıra Hobbes'un hayatı, aldığı eğitim ve bilimsel yöntemini şekillendiren Avrupa gezileri de çalışma kapsamında ele alınmaktadır. Dolayısıyla bu çalışma bir yandan Hobbes'a ilişkin bir bilimsel biyografi sunmayı hedeflemekte, diğer yandan düşünürün yaşadığı tarihsel dönemdeki bilimsel ve siyasal ortam ile düşünür ve Leviathan eseri arasındaki ilişkileri ortaya koymayı amaçlamaktadır.

Hobbes kendisine ait siyaset kuramını belirli bir çerçeve içerisinde sunmayı başarmış ve siyasi iktidar kavramını ve mutlak iktidarın zorunluluğunu tutarlılık içerisinde açıklayabilmiş önemli bir düşünürdür (Ağaoğulları vd., 1994:161). Modern felsefenin kurucuları arasında yer alan düşünür (Cevizci, 2013:85), kendisinin gerçek anlamda politika bilimini kuran ilk kişi olduğuna da inanmaktadır (Cevizci, 2013:86; Ağaoğulları vd., 1994:162). Hobbes'a ait devlet kuramının bir bütün halinde bulunabileceği eseri Leviathan ise, devletin kökeninin ne olduğuna toplumsal sözleşme üzerinden bir açıklama getirmekte ve yönetilenler arasında gerçekleştirilen toplumsal sözleşme ile oluşturulan (kurulan) devletin işleyişine ilişkin detaylara da yer vermektedir.

Leviathan'ın (devletin) sunuş bölümünde devlet, yapay bir insan bedenine benzetilmektedir. Hobbes eserinde bu yapay insan bedenini (devleti), doğal bir insan bedeni gibi incelemektedir. Hobbes'a göre yönetilenler (uyruklar) arasındaki toplumsal sözleşme ile kurulan devlete (yapay insana) ruhunu veren şey ise, sözleşme sonucu doğan egemenliktir. Dolayısıyla devlete (yapay insan bedenine) canlılık ve hareketlilik kazandıran egemenlik (yapay ruh) iken, egemen güç tarafından istihdam edilen kamu görevlileri, doğal bir insan vücudundaki eklem ve organlara benzetilmektedir. Hobbes'a göre egemenlik makamına bağlı bu eklem ve organlara görevlerini yaptıran şey ise kamu otoritesi tarafından verilen ödül ve cezalardır. Bu bakımdan Hobbes ödül ve cezaları, doğal bir insan bedenindeki sinirlere benzetmektedir (Hobbes, 2017:17). Yazar, devletin kurulması ve sonrasında işleyişine ilişkin ipuçlarını, görüldüğü üzere henüz eserin sunuşunda vermektedir. Yapay insan bedenine ve o yapay bedenin işleyişine dayanan devlet görüşüyle Hobbes, sonradan Toplumsal Sözleşme Kuramları olarak adlandırılacak akımın ilk temsilcisidir.

Hobbes'un yazarlığının doruk noktası ve en önemli eseri olarak kabul edilen Leviathan üzerine özellikle Siyaset Bilimi alanında çok sayıda çalışma bulunmaktadır. Bu çalışmaların genelde Hobbes'un ortaya koyduğu insan doğası, doğa durumu, doğa yasaları, toplumsal sözleşme, devlet, devlet çeşitleri, egemenlik ve egemen gücün/uyrukların yetki, sorumluluk ve görevleri, meşruiyet gibi kavramları ve kabulleri incelediği, ancak sözleşme ile kurulmuş olan devletin "işleyişine" ilişkin konuları ya es geçtikleri ya da bir bütün olarak ele almadıkları ifade edilebilir. Bu çalışmada da Hobbes ve onun Leviathan'ı üzerine genelde yapılmış olan çalışmalara benzer şekilde, devletin oluşumuna ve kökenine ilişkin eserde yer alan kavramlar ve kabuller incelenmektedir. Bu yolla Hobbes'a göre devletin var olmadığı durum ile var olduğu durum arasındaki farklar ile doğa durumu, doğa yasaları, doğal hak, egemenlik, meşruiyet gibi kavram ve kabullerin ne anlama geldiğinin açıklanması hedeflenmektedir. Ancak çalışmada devletin ortaya çık(arıl)masından (doğuşundan), biçiminden ve gücünden bahsettikten sonra, Hobbes tarafından devletin diğer kısımları olarak adlandırılan kamusal kuruluşlar, devletin organları ve eklemleri olarak adlandırılan kamu görevlileri, bu organ ve eklemleri hareket ettiriciler olarak adlandırılan cezalar ve ödüller ile emir ve tavsiye sözcüklerinin analizi sonucunda çerçevesi çizilen danışmanlık olgusu ele alınmaktadır. Bunun nedeni, toplumsal sözleşme sonucu var edilen devletin işleyişinin hangi ilkelere göre kurgulandığını keşfetmektir.

Bu amaçlarla çalışmanın ilk bölümünde Hobbes'un hayatı, aldığı eğitim, işi sayesinde çıktığı ve düşüncelerini şekillenmesinde çok önemli bir yeri olan Avrupa gezileri, hayatı boyunca ortaya koyduğu eserler ve Leviathan'ın onlar içerisindeki yeri gibi konular görece detaylı bir incelemeye tabi tutulmaktadır. Çalışmanın ikinci bölümünde ise, Hobbes'un yaşadığı tarihsel dönemin koşulları ve tanıklık ettiği iki büyük devrim incelenmektedir. Bu kapsamda ilk olarak, 17. yüzyılda Hobbes'un tanıklık ettiği bilimsel devrim ve kendi bilimsel yöntemi ortaya konulmakta ve sonrasında, İngiliz İç Savaşı ve İngiltere'deki politik devrim süreci, düşünürün yaşam süresi ile sınırlanarak, ele alınmaktadır. Çalışmanın son bölümü ise, Leviathan eseri üzerinde gerçekleştirilen görece detaylı bir incelemeye ayrılmaktadır. Bu doğrultuda, öncelikle devletin ortaya çıkma 
nedenleri ve süreci ele alınmakta, sonrasında bir kere oluşturulmuş olan devletin işleyişine ve yönetimine ilişkin kavramlar ve kabuller incelenmektedir. Dolayısıyla çalışmada, Hobbes özelinde bilimsel biyografi niteliği taşıyabilecek bir inceleme yapılmasının yanı sıra, dönemin tarihsel-sosyolojik gelişmeleri ile dönemin bilimsel gelişmeleri arasındaki ilişki değerlenlendirilmektedir. Esere dönük inceleme ise kavram analizi sayılabilecek bir yöntemi de içermektedir.

\section{THOMAS HOBBES ÜZERINE}

Çalışmanın bu bölümünde Hobbes'un hayatı, aldığı eğitim, işi sayesinde çıktığ1 ve düşüncelerini şekillenmesinde çok önemli bir yeri olan Avrupa gezileri, hayatı boyunca ortaya koyduğu eserler ve Leviathan'ın onlar içerisindeki yeri gibi konular görece detaylı bir incelemeye tabi tutulmaktadır. Buradaki amaç, sınırlı da olsa Hobbes'a dair bilimsel biyografisi niteliğini taşıyabilecek bir döküm ortaya koymak ve bu yolla, yazarı ve eserini neden-sonuç ilişkileri içerisinde tahlil edebilmektir.

\subsection{Hobbes'un Hayatı ve Eğitimi}

Babasının ismini alan Thomas Hobbes (Martinich, 2010:2; Duncan, 2019), 5 Nisan 1588 yılında İngiltere'de Malmesbury yakınında bulunan Westport'ta, bir köy papazının oğlu olarak dünyaya gelmiştir (Aubrey, 1982:150; Zabunoğlu, 1959:219; Gökberk, 1985:280; Ağaoğullar1 vd., 1994:162; Martinich, 2010:2; Cevizci, 2013:91; Güriz, 1955:298). Bir erken doğum sonucu dünyaya gelen ${ }^{1}$ Hobbes'un fakir, önemsiz, alkolik, aksi, yeteneksiz, sorumsuz, kavgacı ve muhtemelen eğitimsiz bir papaz olarak nitelenebilecek babası ${ }^{2}$, ailesini ve onu Hobbes henüz on altı yaşındayken terk etmiştir (Aubrey, 1982:148; Tannenbaum ve Schultz, 2006:235; Tuck, 2016:14; Ağaoğulları vd., 1994:162; Martinich, 2010:4; Zabunoğlu, 1959:219; Ryan, 2013:411; Duncan, 2019). $\mathrm{Bu}$ duruma rağmen, çok zeki bir çocuk olan ve dört yaşında okuma-yazmayı öğrenen Hobbes (Tannenbaum ve Schultz, 2006:235; Tuck, 2016:14; Martinich, 2010:8), amcasının ${ }^{3}$ sayesinde iyi bir eğitim görüp, Oxford Üniversitesi Magdalen Hall'de ${ }^{4}$ lisans eğitimi almaya başlamıştır ${ }^{5}$ (Aubrey, 1982:149-150; Tannenbaum ve Schultz, 2006:235; Ağaoğulları vd., 1994:163; Martinich, 2010:8; Ryan, 2013:411; Duncan, 2019; Cevizci, 2013:92).

Üniversitede sınıf arkadaşlarının çoğundan genç olan Hobbes, üniversite eğitimi öncesinde altı yıl boyunca Latince ve Yunanca dillerini öğrenmiş ${ }^{6}$ ve bu ona, eğitim hayatında kolaylık sağlamıştır (Martinich, 2010:10; Cevizci, 2013:92). Üstelik Latince ve Yunanca ile birlikte, Fransızca ve İtalyanca'yı da anadili olan İngilizce kadar konuşup yazabilmektedir (Tuck, 2016:14). Üniversitede skolastik felsefe, mantık ve Aristoteles eğitimi almıştır (Çapar ve Yıldırım, 2012:83). Ancak üniversitede derslere düzenli olarak katılmamıştır (Martinich, 2010:12). Nitekim Hobbes, girdiği üniversitede verilen skolastik felsefe eğitiminden pek haz almamıştır (Ağaoğulları vd., 1994:163; Cevizci, 2013:92; Güriz, 1955:299). Çünkü verilen eğitim dini bir eğitim ve felsefe eğitimi adına verilenler Aristocu geleneğe uygun öğretilerdir (Malcolm, 2006:16). Hobbes muhtemelen on beş yaşında girdiği üniversiteden, yirmi yaşında mezun olmuş ve mesleki hayatına bir öğretmen/yazar olarak başlamıştır (Tannenbaum ve Schultz, 2006:235-236; Ağaoğulları vd., 1994:163; Bektaş, 1993:179).

1 Çoğu kaynağa göre Hobbes, annesinin İspanyol Donanması'nın geldiği söylentisinin yayılması ile birlikte doğuma erken girmesi sonucu yedi aylıkken dünyaya gelmiştir. Bu korku sonucunda gerçekleşen erken doğumu ile ilgili Hobbes hayatı boyunca sik s1k espri yapmıştır: "Korku benim ikizimdir, ne de olsa birlikte doğmuştuk" (Aubrey, 1982:150; Tuck, 2016:14; Ağaoğulları vd., 1994:162; Tannenbaum ve Schultz, 2006:235 Martinich, 2010:2; Ryan, 2013:411; Malcolm, 2006:14-15; Cevizci, 2013:91-92; Güriz, 1955:299). Diğer yandan, Hobbes'un annesi hakkında çok fazla şey bilinmemektedir. Ayrıntılı bilgi için bkz.: Martinich, 2010:2; Duncan, 2019.

2 Hobbes'un hayatını konu alan bir çalışma yapan ve 1634'den beri onun dostu olan John Aubrey Hobbes'un babası için, “Londra'nın kim bilir bilmem neresinde" ölüme doğru yürüdüğünü not düşmektedir (Tuck, 2016:14; Martinich, 2010:4-5-7-103; Malcolm, 2012:779).

3 Hobbes'un babası Thomas Hobbes evi terk ettikten sonra Hobbes'a, destek veren büyük amcasının ismi Francis'tir. Malmesbury'de ilçe vekili ve kasaba başyargıcı olan Francis, Thomas'ın eğitimine destek olmuştur (Aubrey, 1982:149; Martinich, 2010:6).

4 Hobbes'un gittiği okul, bütünüyle genel edebiyat ve beşeri bilimlere ilişkin derslerin verildiği bir tür üniversitedir (Tuck, 2016:16).

5 Hobbes’un burada eğitimine ne zaman başladığına ilişkin farklı görüşler bulunmaktadır. Nitekim Hobbes'un okula kayıt yaptırdığına ilişkin belge günümüze ulaşmamıştır. Kimi kaynaklara göre okula başladığı y1l 1602 iken, kimi kaynaklara göre bu yıl 1603 olarak belirtilmektedir. Ancak Hobbes'un okuldan 1608 yılında mezun olduğu kesindir (Martinich, 2010:9-10).

6 Hobbes üniversitede de Latince ve Yunanca üzerine eğitim görmeye devam etmiş ve her iki dilde de mükemmel denebilecek bir seviyeye ulaşmıştır (Zabunoğlu, 1959:219). 
Her ne kadar Magdalen Hall'da aldığı eğitimden çok haz almamış olsa da, bu eğitim Hobbes'a iyi bir iş bulması konusunda yardımcı olmuştur (Malcolm, 2006:17). Muhtemelen iyi, saygın ve parlak bir öğrenci olmasından dolayı, 1608 y1lında Magdalen College'nin müdürü tarafından Hardwick Hall'daki Cavendish ailesine tavsiye edilmiştir (Aubrey, 1982:151; Martinich, 2010:23; Çapar ve Yıldırım, 2012:83; Duncan, 2019). Aristokrat bir aile olan Cavendish ailesinin oğluna özel öğretmenlik yapması için işe alınan Hobbes, öğrencisi ile birlikte Avrupa kıtasına yaptığı seyahatlerde dönemin önde gelen bazı bilim adamları ve filozofları ile tanışma firsatı bulmuştur (Tannenbaum ve Schultz, 2006:236; Güriz, 1955:299). Ayrıca 1608 yılında William Cavendish'in evinde başladığı bu meslek ona, efendilerinin kütüphanelerini rahatlıkla kullanma ve bilgilerini geliştirme imkânı da sağlamıştır (Ağaoğulları vd., 1994:163; Duncan, 2019). Hobbes malikânesine yerleştiği Cavendish ailesi ile ilişkisini hayatının sonuna kadar devam ettirmiştir (Zabunoğlu, 1959:219; Duncan, 2019). Hayatının geri kalanını ya Cavendish ailesinin ya da komşu diğer ailelerin yanında bir sekreter, öğretmen, finans sorumlusu veya bir genel danışman olarak çalışarak geçirmiştir (Tuck, 2016:17; Ryan, 2013:412). Hobbes hayatı boyunca hiç evlenmemesinin yanı sıra, ne siyasette görev almış ne de akademide çalışmıştır (Tannenbaum ve Schultz, 2006:236).

\subsection{Avrupa Gezileri ve Düşüncelerinin Gelişimi}

Hobbes'un mesleği sayesinde Avrupa'ya yaptığı ilk gezi, 1610 yılında William Cavendish ${ }^{7}$ ile birlikte gerçekleşmiştir. Gezi kapsamında Hobbes ve kendinden sadece üç yaş küçük olan öğrencisi, 1610-1615 yılları arasında Fransa ve İtalya’yı dolaşma firsatı bulmuşlardır ${ }^{8}$ (Tuck, 2016:19; Ağaoğulları vd., 1994:163; Cevizci, 2013:93). Hobbes bu ülkelerde, bilimin kurucusu olarak gördüğü Kepler ve Galileo gibi (Cevizci, 2013:97) farklı aydınların çalışmalarını incelemiştir. İngiltere'ye döndükten sonra Francis Bacon ile tanışma firsatı bulan Hobbes, öğretisinden sonraları çok etkileneceği Bacon'un bir süre için sekreterliğini (yazmanlığını) de yapmıştır ${ }^{9}$ (Gökberk, 1985:280; Zabunoğlu, 1959:219-223; Ağaoğulları vd., 1994:163; Malcolm, 2006:20; Hill, 2016:228).

Aynı yıllarda Hobbes, Thukydides'in Peloponnesos Savaşının Tarihi eserini İngilizce'ye çevirmiştir ve bu çeviri Hobbes'un ilk eseri olarak 1629 yılında yayımlanmıştır (Ağaoğulları vd., 1994:163). Hobbes'un bu çeviriye ne zaman başladığı ya da çevirinin ne kadar sürdüğüne ilişkin bir bilgi olmamakla birlikte, çeviriyi yapmaktaki amacının siyasi bir faaliyet gerçekleştirmek olduğu söylenebilir ${ }^{10}$ (Martinich, 2010:90). Çevirinin önsözünde Hobbes, tarihi inceleyip araştırmanın bugün ve geleceğe sunacağı katkının altını çizmiş ve tarihi bilmenin, geleceğe egemen olmak anlamına geldiğini ileri sürmüştür. Bu bakımdan Hobbes'un bu görüşünün, Bacon'ın "bilmek, egemen olmaktır" görüşüne oldukça yakın olduğunu ve ondan etkilendiğini söylemek yanlış olmayacaktır ${ }^{11}$ (Gökberk, 1985:281).

Hobbes'u Cavendish ailesinin konutunda, 1608 yılında işe alan Baba William Cavendish'in 1626 yılındaki ölümü sonrasında, onun yerine geçen ve Hobbes'un öğretmenliğini yaptığı dostu oğul William Cavendish'in de 1628 y1lında 38 yaşındayken ölmesi üzerine ${ }^{12}$ Hobbes, bir süreliğine Cavendish ailesine hizmet vermeyi bırakmıştır $^{13}$ (Martinich, 2010:89-94-95; Tuck, 2016:30).

7 Hobbes'un birlikte Avrupa'ya gittiği William Cavendish, babasıyla aynı ismi taşımaktadır. Hatta kendi oğlunun ismi de William Cavendish'tir. William Cavendish ile ilgili isim karışıklığının olmaması için bkz.: Martinich, 2010:29-30; Duncan, 2019.

8 Hobbes'un İtalyanca ve Fransızca bilgisini bu seyahatte geliştirdiği düşünülmektedir (Cevizci, 2013:93).

9 Hâkim olan görüşe göre Hobbes'un Bacon için çalıştığı dönem, Bacon'ın rüşvet aldığı için adalet bakanlığından azledilmesinden sonraki döneme (1620'li yıllara) denk gelmektedir. Hobbes'un Bacon için yaptığ 1 işler arasında, dikte edilenleri yazmak ve uluslararası piyasa için bazı denemelerin Latince'ye çevrilmesi gibi işler bulunmaktadır (Martinich, 2010:75-76; Tuck, 2016:28; Duncan, 2019; Hill, 2016:23).

10 Hobbes'un Thukydides'in eserini çevirmek istemesinin sebebi, onun yönetimde monarşiyi üstün tutması ve demokrasiyi hor görmesi olabilir (Martinich, 2010:90; Ağaoğulları vd., 1994:163; Ryan, 2013:412). Nitekim Hobbes'un, Thukydides'in fikirlerinin etkisi altında kaldığını ve monarşi savunucusu olduğunu ileri sürmek mümkündür (Zabunoğlu, 1959:223). Zaten Hobbes, Thukydides’i en sevdiği tarihçi olarak ilan etmektedir (Malcolm, 2006:20; Cevizci, 2013:93).

11 Ancak diğer taraftan Bacon'ın radikal ampirizminin, Hobbes'un rasyonalizmi ile taban tabana zit olduğu söylenebilir. Nitekim Hobbes'a göre "bilimsel terimler maddesel cisimleri işaret etse de, bilimsel önermeler ampirik değil, evrensel ve zorunlu olarak doğrudur" (Martinich, 2010:76-77).

12 Hobbes'un ilk siyasi çalışması olarak anılabilecek olan Thukydides'in eserinin çevirisi, Hobbes tarafindan dostu ve öğrencisi oğul William Cavendish'e hediye edilmiştir (Ryan, 2013:412).

13 O dönemde Cavendish ailesinin genç üyesi torun William Cavendish'in yaşının küçük olması, Hobbes'un ona eğitim verebilmesinin "şimdilik" önüne geçmiştir (Martinich, 2010:95). 
Bu süreçte Hobbes, Avrupa'ya ikinci gezisini, 1629 yılında yanında işe girdiği Sir Gervase Clifton'ın kendi adını taşıyan oğlu ile birlikte, 1629-1631 yılları arasında gerçekleştirmiştir (Malcolm, 2012:821; Martinich, 2010:34-96; Ağaoğulları vd., 1994:163). Bu gezide ikili; Paris, Lyon, Cenevre ve Orleans'ta bulunmuşlardır

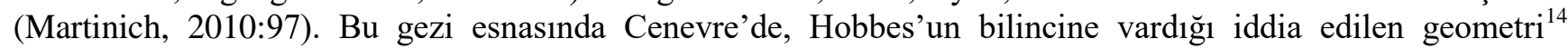
(Aubrey, 1982:151-152; Martinich, 2010:97-98), ilerleyen yıllarda Hobbes'un felsefesine fazlasılyla etki etmiştir (Martinich, 2010:98).

Hobbes ikinci kez çıktığı Avrupa gezisinden dönüşte, eski öğrencisi oğul William Cavendish'in eşi Christian tarafından tekrar Cavendish ailesinin yanında işe alınmıştır. Hobbes'un bu sefer eğitim verdiği kişi, torun William Cavendish olmuştur (Malcolm, 2012:815; Martinich, 2010:100). Cavendish ile birlikte, Avrupa'ya 1634 yılında üçüncü kez seyahat eden Hobbes, 1636 yılına kadar Kıta Avrupa'sında kalmış ve bir kez daha Fransa ve İtalya'yı ziyaret etmiştir. Kendisinin üçüncü kez gerçekleştirdiği bu gezinin, Hobbes için en önemlisi olduğu ifade edilebilir (Malcolm, 2012:815; Tuck, 2016:35). Öyle ki Hobbes bu sefer, çağın önde gelen bilim insanları ile bir araya gelme firsatı yakalamıştır (Martinich, 2010:104). Bu kapsamda Hobbes, daha önce çalışmalarını inceleme firsatı bulduğu Galileo ile 1636 yılında muhtemelen Floransa'da tanışırken ${ }^{15}$; Renê Descartes ${ }^{16}$ Pierre Gassendi gibi çağın ünlü filozoflarılla bir araya gelmesini teşvik eden Peder Marin Mersenne $^{17}$ ile de bu gezide Fransa'da tanışmıştır (Aubrey, 1982:161; Malcolm, 2012:835-863-864; Martinich, 2010:104-105; Ağaoğulları vd., 1994:163; Zabunoğlu, 1959:223; Duncan, 2019; Cevizci, 2013:93-94).

\section{3. İlk Özgün Eserleri ve Sürgünde Geçen Yıllar}

Hobbes üçüncü kez çıktığı Avrupa gezisinden İngiltere'ye döndügünde, torun Cavendish'e hocalık yapmayı artık bırakmış ve neredeyse 50 yaşına gelmiştir. Ancak ihtiyaçları olması durumunda, torun Cavendish ve annesi Christian'a yardım etmeye hazır olan Hobbes'un, onlarla birlikte hizmetkâr olarak kalmasını Cavendish ailesi de istemiştir. Aslında Hobbes'un bu dönemdeki isteği, zamanının mümkün olduğunca büyük bir kısmını bilimsel çalışmalarına ayırmak olmuştur (Martinich, 2010:107). Nitekim Kıta gezileri boyunca ciddi bir şekilde felsefe ile ilgilenmiş ve 50 yaşına doğru siyasal görüşlerini sistemli bir şekilde ortaya koyabilecek birikime ve donanıma sahip olduğunu düşünmeye başlamıştır (Ağaoğulları vd., 1994:163; Zabunoğlu, 1959:220).

Diğer yandan Hobbes'un Avrupa gezisinden dönmüş olduğu dönemde İngiltere'de, kral ile parlamento arasında yıllardır süren büyük bir sürtüşme bulunmaktadır. ${ }^{18} \mathrm{Bu}$ sürtüşmenin temelde, egemenliğin kimin elinde olması gerektiği sorunu üzerine olduğu ifade edilebilir (Ağaoğulları vd., 1994:163-164). 1630'ların sonu ile birlikte Hobbes, ilgilisini iyiden iyiye ilgisini politika alanına kaydırmıştır (Malcolm, 2006:26-27). Hatta Hobbes 1640 yılında, Kısa Parlamento olarak bilinen ve yalnızca 18 günlügüne hayat bulan parlamentoya milletvekili olmaya çalışmışsa da, bunu başaramamıştır (Malcolm, 2006:27).

14 Gezisi sırasında bir asilzadenin evinde Hobbes'un rast geldiği Öklit'in Elementler eserinin Pisagor bağıntısı ile ilgili kısmı, Hobbes'u çok etkilemiştir (Aubrey, 1982:152). Hatta Hobbes'un bu teorem sonucunda geometriye aşık olduğu bile söylenebilir (Ryan, 2013:412; Cevizci, 2013:93). Geometriye dair Hobbes'u cezbeden şeyin, geometrideki şüpheye yer bırakmayan bir temel üzerinde bir şeyle diğeri arasında bağlantı kurma yöntemi olduğu söylenebilir. Diğer bir deyişle Hobbes'u şaşırtan şeyin, geometrinin yöntemi olduğu ifade edilebilir (Martinich, 2010:98-99; Cevizci, 2013:98; Hill, 2016:228; Bektaş, 1993:179).

15 Hobbes bu yıllarda, insanın tüm düşünsel ve eylemsel süreçleri de dâhil olmak üzere var olan her şeyin devinimden başka bir şey olmadığını iddia etmektedir. Özellikle optik ve teleskoplara olan ilgisinin onu, Galileo ile buluşturan temel sebep olduğunu ifade etmek mümkündür (Martinich, 2010:104).

16 Hobbes, Descartes'in felsefesinin etkisi altında kalmış olmakla birlikte, ona karşı da gelmiştir. Hobbes, Descartes'in kendi isteği üzerine, Descartes'in Illk Felsefe Üzerine Meditasyonlar isimli eserine yayınlanmadan önce eseri eleştiren bir yazı kaleme almış ve bu yazı Descartes'e gönderilmiştir. Hatta sonrasında, bu eleştiri ve Descartes'in cevabı birlikte 1641 yılında basılmıştır (Zabunoğlu, 1959:220; Gökberk, 1985:280; Duncan, 2019; Martinich, 2010:189; Malcolm, 2006:24-25-28; Cevizci, 2013:94).

17 Avrupa'nın birçok düşünürü ile irtibatta olan Mersenne (Tuck, 2016:35), o dönemde Hollanda'da adeta herkesten saklanmakta olan Descartes ile Hobbes arasında bir iletişim köprüsü kurmuştur. Öte yandan rivayete göre, Hobbes ile Descartes'in yüz yüze görüşmesi ancak 1648 y1lında gerçekleşebilmiştir (Tuck, 2016:18-37; Malcolm, 2012:825-826; Martinich, 2010:196).

181628 yılında parlamento; keyfi hapsetme, zorla asker yerleştirme (kralın sürekli bir orduya sahip olması bağlamında), parlamento onayı olmadan vergi koyma gibi konularda bir şikayet listesi mahiyetinde olan Haklar Bildirgesi'ni (Petition of Rights) çıkarınca Kral I. Charles, 1629 yılında parlamentoyu kapatmıştır ve parlamento 1640 yılına kadar toplanamamıştır (Martinich, 2010:99; Çapar ve Yıldırım, 2012:83; Ağaoğulları vd., 1994:167-168; Hill, 2016:24). 
Gün geçtikçe artarak devam eden bu sürtüşmenin sonucunda İngiltere'de sivil savaş patlak verdiğinde, Hobbes'un haberi olmadan The Elements of Law, Natural and Politic ${ }^{19}$ isimli eserinin el yazmaları elden ele dolaşmaya başlamıştır. ${ }^{20}$ Eser, barış ve refahın korunması ile savaştan kaçınılması için yöneten ve yönetilenlerin neler yapması gerektiğini konu almaktadır. Kral ile parlamento arasındaki çekişmede, kraldan yana bir tavır tutunmayı ima eden eser sebebi ile Hobbes, parlamentonun kendisini hapis edebileceğini ya da öldürebileceğini düşünerek 1641 yılında Fransa'ya kaçmak zorunda kalmıştır ${ }^{21}$ (Ryan, 2013:412; Martinich, 2010:185-186; Bektaş, 1993:179). Hobbes Fransa'da geçirdiği, bir nevi sürgün olarak adlandırılabilecek bu dönem içerisinde 1646-1648 yılları arasında, gelecekte Kral Charles (II) olarak tahta geçecek olan Kral Charles (I)'in oğluna matematik dersleri de vermiştir (Martinich, 2010:202; Ağaoğulları vd., 1994:169; Çapar ve Yıldırım, 2012:83; Zabunoğlu, 1959:220).

Thomas Hobbes'un o dönemde bas1labilen The Elements of Philosophy ${ }^{22}$ isimli eseri ise, aslında 3 bölümden oluşmaktadır (Gökberk, 1985:281). Siyaset ile ilgili bölümü (1642) De Cive (yurttaşlık/yurttaş üstüne) ismiyle, daha bilimsel kısmı (1655) De Corpore (madde/cisim üstüne) ismiyle ve en son kısmı (1658) De Homine (insan/insan doğası üstüne) ismiyle yayınlanmıştır (Tannenbaum ve Schultz, 2006:236; Gökberk, 1985:281). Eserin ilk bölümü olan ve 1642 'de basılan De Cive, Hobbes'un yayınlanan ilk siyaset felsefesi metni olarak anılmaktadır. Bununla birlikte De Cive, önceden de belirtildiği üzere daha kapsamlı bir çalışma olan The Elements of Philosophy'nin ilk parçasıdır. 1655'de yayınlanan De Corpore bölümü ise mantık, dil, yöntem, metafizik, matematik ve fizik konularını içermektedir. Eserin son bölümü olan ve 1658 yılında basılan $D e$ Homine'de ise, fizyoloji ve optik hakkındaki konulara odaklanılmaktadır (Cevizci, 2013:95; Duncan, 2019).

Eserleri arasında en başta gelen Leviathan ${ }^{23}$, İngiltere'de iç savaşın sona ermesi ve kralın idam edilmesinden 2 y1l sonra 1651 yılında, hem İngiltere'de hem de Fransa'da yayınlanmıştır ${ }^{24}$ (Tannenbaum ve Schultz, 2006:236; Ryan, 2013:411; Ağaoğulları vd., 1994:170; Martinich, 2010:144). Hobbes'un devlet öğretisinin çok büyük bir kısmının yer aldığı bu eserin ismi (Gökberk, 1985:281), o zamana dek Eski Ahid'in birçok kısmında bir çeşit su canavarı olarak kullanılagelmiştir ${ }^{25}$ (Ağaoğulları vd., 1994:169; Güriz, 1955:302). Hobbus'un Leviathan eseri, hem İngiltere'de hem de Fransa'da kral/monarşi destekçilerinin tepkisini çekmiştir. ${ }^{26}$ Sığındığ 1 Fransız hükümeti ile arası açılan Hobbes, kendisini Fransa'da güvende hissetmemesinden ötürü, 1652 yılında İngiltere'ye geri dönmüştür (Ağaoğulları vd., 1994:170; Martinich, 2010:247). İngiltere’ye dönüşü sonrasında Cavendish ailesinin yanına yerleşen Hobbes, kendi yapıtlarında ortaya koyduğu öğretiye uyarak, dönemin Cromwell iktidarına boyun eğmiş ve siyaset ile ilgilenmemeye gayret göstermiştir (Ağaoğulları vd., 1994:170; Hill, 2016:221).

Cromwell'in ölümünden sonra, onun yerine geçen oğlu devleti yönetmekte başarılı olamamış ve 1660 y1lında

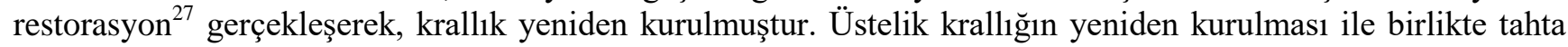

$19 \mathrm{Bu}$ eserde, Hobbes'un daha sonraki siyaset felsefesinde bulunan temel fikirleri bulmak mümkündür (Tannenbaum ve Schultz, 2006:236; Ağaoğulları vd., 1994:164). Nitekim Hobbes sonraki eserleri olan De Cive ve Leviathan'da da, egemenliğin mutlak olduğunu iddia etmiş ve bu eserdeki iddialarına bağlı kalarak, onları geliştirmiştir (Malcolm, 2006:28).

20 Hobbes'un eseri 1640 yılında tamamlamış olduğu, ancak o dönemde eserin yayımlanmadığı ve kralı destekleyen bazı bölümlerin elden ele dolaştı̆̆ bilinmektedir (Ağaoğulları vd., 1994:164). Ayrıca Hobbes'un eseri Kısa Parlamento'nun dağılmasından yalnızca 4 gün sonra dolaşıma girmiş ve kralcı bir tutum sergilediğinden dolayı parlamento taraftarlarını rahatsız etmiştir (Malcolm, 2006:27). Eser 1650-51 yıllarında iki kısım halinde, Human Nature ve De Corpore Politico başlıklarıyla yayımlanmıştır (Martinich, 2010:137; Cevizci, 2013:94).

211640 yılında, Uzun Parlamento olarak adlandırılan parlamento kurulmuş ve Hobbes iyiden iyiye hedef haline gelmiştir (Malcolm, 2006:28). Nitekim İngiliz İç Savaşı’nın sonunda, parlamentocu kanat galip gelmiş ve Kral I. Charles 1649 yılında idam edilmiştir. Galip gelenler General Cromwell'in idaresi altında kısa süreli bir diktatörlük kurmuşsa da (1653 ile 1658 yılları arasında), Cromwell'in ölümünden sonra İngilizler, Kral I. Charles'ın oğlunun yönetimi altında monarşiyi geri getirmişlerdir (Tannenbaum ve Schultz, 2006:237-238; Ağaoğulları vd., 1994:164; Malcolm, 2006:32).

22 Hobbes, bu uzun döneme yayılan eserinin planını 1630'lu yılların sonunda oluşturmuştur. Eser her şeyi cisim, insan, yurttaş üçlemesinden birine indirgeyebilmek amacıyla kapsamlı bir gerçeklik irdelemesi olarak tasarlanmıştır (Martinich, 2010:136-199).

23 Hobbes'un diğer eserlerinin en önemli kısımları, Leviathan'da tekrar edilmiştir. Bu bakımdan eserin, bir sentez niteliğinde olduğunu ileri sürmek mümkündür (Zabunoğlu, 1959:222). Ayrıca bu eser, hemen hemen herkes tarafindan Hobbes'un yazarlık veriminin doruk noktası olarak anılmaktadır (Cevizci, 2013:95).

24 Leviathan eserinin çok kısa bir sürede yazıldığı yönünde iddialar için bkz. (Martinich, 2010:245).

25 Leviathan'dan nasıl söz edildiğine ilişkin örnekler için bkz. (Ağaoğulları vd., 1994:169-170; Güriz, 1955:302).

26 İngiliz kralcılar, Hobbes'un kuramında kralın tanrısal haklarına yer vermemesinden ve iç savaşın durdurulması için kral karşısında parlamento egemenliğinin de bir alternatif olarak kabul edilmesinden rahatsız olmuştur (Ağaoğulları vd., 1994:170).

27 Restorasyon ile ilgili daha fazla bilgi için bkz. https://www.britannica.com/topic/Restoration-English-history-1660; 05.11.2019. 
geçen kral, Hobbes'un Fransa'da matematik dersi verdiği eski öğrencisi, Kral II. Charles'tır (Ağaoğulları vd., 1994:170). Eski öğrencisinin kral olması ile birlikte her ne kadar Hobbes'un itibarı artmış olsa da ${ }^{28}$ parlamento, Hobbes'un eserleri başta olmak üzere, ateist nitelikli eserleri incelemek için bir komisyon ${ }^{29}$ kurmuştur. Bunun üzerine Hobbes siyaset, ahlak, din gibi tartışmalı konularda yazmama sözü vermiş ve soruşturmadan kurtulmuştur (Ağaoğulları vd., 1994:171).

Ancak Hobbes'un sözünü tutmadığını ileri sürmek mümkündür. Nitekim eserleri arasında yer alan ve 1668 yılında tamamlanan, ancak ölümünden sonra yayınlanan Behemoth, ${ }^{30}$ İngiliz siyaset ve iç savaş tarihini konu almaktadır $^{31}$ (Tannenbaum ve Schultz, 2006:236). Ayrica Hobbes, Leviathan eserini de Latince'ye 1668 y1linda çevirmiştir (Martinich, 2010:375). Hobbes ilerlemiş yaşında rağmen, önceden beri ilgi duyduğu matematik ve geometri ile ilgilenmeye devam etmiş ve bu konularda Oxford'daki hocalar ile tartışmalara girmiştir. 1673-1676 yılları arasında Homeros'un bütün eserlerini İngilizce'ye çevirip yayınlanmasını da sağlamıştır (Ağaoğulları vd., 1994:171).

Özetle, Hobbes 1679 yılında Cavendish ailesinin şatosunda yakalandığı hastalık sonucunda ölene kadar (Ağaoğullar1 vd., 1994:171; Zabunoğlu, 1959:221-222; Duncan, 2019; Cevizci, 2013:94), kısmen İngiltere'de kısmen de Paris'te yaşamıştır (Gökberk, 1985:281). Hobbes'un yaşadığı yıllarda İngiltere'nin bir anarşi döneminin içinde bulunması sebebiyle düşünür, bilimsel çalışmalarını huzur içinde gerçekleştirebilmek amacıyla yaşamının neredeyse yirmi yılını Fransa'da geçirmiştir (Gökberk, 1985:280-281-286). Her ne kadar siyaset ile ilgili çalışmaları ile tanınmışsa da düşünür; bilim, matematik ve din gibi konularda da eserler vermiştir (Tannenbaum ve Schultz, 2006:236; Martinich, 2010:104). Korkak ve çekingen bir karaktere sahip olmasını erken doğumu ile ilgili hikâyeye bağlayan Hobbes, siyasal kuramında da korku, güvensizlik gibi duygulara fazlaca yer vermiş ve sürekli olarak güven ve istikrar arayışında olmuştur (Ağaoğulları vd., 1994:162; Tannenbaum ve Schultz, 2006:235).

\section{TARİHSEL DÖNEM VE KOŞULLAR ÜZERİNE}

Çalışmanın bu bölümünde, Hobbes'un yaşadığı tarihsel dönemin koşulları ve tanıklık ettiği iki büyük devrim incelenmektedir. Bu kapsamda ilk olarak, 17. yüzyılda Hobbes'un tanıklık ettiği bilimsel devrim ve kendi bilimsel yöntemi ortaya konulmakta ve sonrasında, İngiliz İç Savaşı ve İngiltere'deki politik devrim süreci, düşünürün yaşam süresi ile sınırlanarak, ele alınmaktadır.

\subsection{Hobbes ve İki Büyük Devrim}

Hobbes'un Leviathan eserini detaylıca inceleyebilmek için yaşadığı dönemin özelliklerini de incelemek gerekmektedir. Bu bağlamda Hobbes'un, 17. yüzyılda gerçekleşen iki büyük devrime tanıklık ettiği ifade edilebilir (Cevizci, 2013:87). Bunlardan ilki olan entelektüel ya da bilimsel devrim, Hobbes'un eserlerindeki bilimsel yöntemini belirlemiştir. Üstelik Hobbes bilimsel devrimden yalnızca etkilenmemiş, aynı zamanda bu devrime doğrudan katkıda da bulunmuştur. Dolayısıyla Hobbes'un bilimsel devrim açısından dönemin diğer düşünürleri gibi ilerici olduğu ileri sürülebilir (Cevizci, 2013:87). Diğer taraftan Hobbes, İngiliz İç Savaşı'na ve politik devrimine de tanıklık etmiştir. Kral ile parlamento arasındaki egemenliğin kimin elinde bulunması gerektiği sorunu üzerinde yükselen iç savaş, Hobbes'un Leviathan eserinde doğrudan bir karş1lık bulmuştur. Hobbes'un politik devrim bakımından hem muhafazakâr hem de ilerici olduğu ileri sürülebilir. Hobbes'un

28 Kralın ailesi ile olan dostluğu ve kral ile aralarındaki özel ilişki sebebiyle Hobbes’a, kral tarafindan yıllık 100 Sterling tutarında bir maaş bile bağlandığı ifade edilmektedir. Ancak bu maaş Hobbes'a, Leviathan eserinde ateist bir duruş sergilediği gerekçesiyle, hemen hemen hiç ödenmemiştir (Martinich, 2010:341; Ağaoğulları vd., 1994:170-171; Zabunoğlu, 1959:221).

29 Bu komisyon 1665 yılındaki veba salgını ve 1666'daki büyük Londra yangını olaylarında, Hobbes'un “tanrısız” kitabı Leviathan'ın sorumlu olup olmadığını araştıracak kadar ileri gitmiştir (Tannenbaum ve Schultz, 2006:235). Sonuç olarak parlamento, yaşanan bu felaketlerden Hobbes'u ve eserlerini sorumlu tutmuş ve eserlerin basımını yasaklamıştır (Zabunoğlu, 1959:221).

30 Ingiltere Iç Savaşlarının Nedenlerinin Tarihi olarak da bilinen eserin ismi (Behemoth), tıpkı Leviathan gibi Eski Ahid'de geçmekte ve insanların karşı koyamadığı çok güçlü bir su canavarını anlatmaktadır (Ağaoğulları vd., 1994:171; Güriz, 1955:302). Bu kitabın yayınlanmamasını, eski öğrencisi-yeni Kral II. Charles rica etmiştir. Kral Hobbes'un fikirlerine katılmakla birlikte, kitabın yayınlanmasının bir kargaşa yaratacağına inanmıştır (Martinich, 2010:373). Dolayısıyla kitap, Hobbes'un ölümünden sonra ancak korsan bir baskı şeklinde yayınlanabilmiştir (Hill, 2016:308).

31 Hobbes bu eserde, İngiliz halkının krala karşı ayaklanmasını, kralın dinsel ve demokratik düşünceleri olması gerektiği gibi baskı altına alamamış olmasına dayandırmıştır (Ağaoğulları vd., 1994:165). Bu anlamda kitap aslında Leviathan'daki ilkelerin takip edilmemesi sonucunda hükümette hangi tür sorunların oluşacağına ilişkin bir vaka incelemesidir (Martinich, 2010:373). 
muhafazakârlığı, egemen monarkın iktidarının sınırsız olması gerektiğini savunmasından kaynaklanmaktadır. Ancak egemenin üzerinde kilise dâhil hiçbir gücün olamayacağını iddia etmesi bakımından ilericidir (Cevizci, 2013:88-89).

\subsubsection{Bilimsel Devrim: Hobbes ve Yöntemi}

Hobbes'un siyaseti anlayış biçimi, Galileo ve Bacon gibi 17. yüzyılın bilim insanlarının keşifleri ile şekillenmiştir (Tannenbaum ve Schultz, 2006:238). Öyle ki bu dönemde, hem yeryüzündeki hem de gökyüzündeki fiziksel cisimleri gözlemleyerek incelemekte ciddi bir artış yaşanmıştır. Böylece bilim insanları, evren ile ilgili doğruluğu yıllardır kabul edilen birçok konudaki dogmalara meydan okumuşlardır. Ayrıca bu bilim insanları, o dönemin klasik yazarlarının aksine, Aristoteles' in teleolojisini ${ }^{32}$ reddetmişler ve Aristoteles, kilise ya da incilin yardımı olmadan keşfedilebilecek olan bilginin varlığını savunmuşlardır (Tannenbaum ve Schultz, 2006:238; Cevizci, 2013:87). Bu bakımdan Hobbes'un modern felsefeyi Descartes, Bacon gibi öncülerine benzer şekilde, eski felsefeden ayırma isteğinin olduğu ifade edilebilir ${ }^{33}$ (Cevizci, 2013:96).

Özellikle Galileo'nun Kopenikçi görüşü destekleyen kanıtı ile dünyanın, evrenin merkezinde olmadığı, aksine güneşin merkezde olduğu görüşü, hareket etmeye dayanan bir bilimsel yöntem gelişmesine yol açmıştır (Tannenbaum ve Schultz, 2006:238). Hobbes, Galileo'nun geometri ile mekanik konusundaki düşüncelerinden etkilenmiş ve dönemin fiziksel dünyanın salt bir mekanik sistem olduğu anlayışına bağlı kalmıştır. Dolayısıyla, bu dünyadaki her şeyin cisimlerin devinimi (hareketi) ilkesine dayanarak, geometrik bir kesinlikle açıklanabilmesinin mümkün olduğunu iddia eden ilkeyi benimsemiş ve din de dâhil olmak üzere dünya dış1 değerler ile ilişkisi olmayan, kapalı mekanik materyalist bir sistem geliştirmiştir (Ağaoğulları vd., 1994:172; Martinich, 2010:146-199; Cevizci, 2013:87-97-110; Bektaş, 1993:179). O da Descartes gibi dünyayı ve insanı açıklamada ilke olarak aklı, araç olarak ise devinimi belirlemiştir. Ancak aklı, ne var olmanın gerekli bir ilkesi ne de metafiziksel bir değer olarak görmüştür. Bunun yerine Hobbes’ta akıl, belirli bir düzene göre düşünme, sayıları karşılaştırma, hesap yapma olarak algılanmıştır. Hobbes'a göre akıl doğal değil de biçimsel olduğundan, doğanın ilkelerini analitik bir yöntemle deney içinde bulmaya yardım etmekte ve araçsallaştırılmaktadır (Martinich, 2010:143; Ağaoğulları vd., 1994:172-173; Cevizci, 2013:107). Bu anlayışa göre akı1, kendiliğinden hiçbir hakikati içermemekte ve düşünceden deneye gidiş gelişlerle biçimlenmektedir (Ağaoğulları vd., 1994:176).

Hobbes'a göre cansız ya da canlı doğada gerçekleşen, maddi ya da ruhi olan her şey, doğal nedenlere bağlıdır. Bu bakımdan Hobbes'tan önce hiç kimse, olaylar arasında hiçbir ayrım yapmaksızın hepsinin doğal nedenlere bağlı olduğunu, diğer bir deyişle doğallıklarını, ileri sürmemiştir. Bu bakımdan Hobbes'un kurduğu sistemin, tutarlı bir natüralizm olduğu ifade edilebilir ${ }^{34}$ (Gökberk, 1985:281; Cevizci, 2013:109). Ayrıca Hobbes bütün nedenlerin doğal olduğunu düşünmenin yanında, bu nedenlerin maddi, diğer bir deyişle cisimsel olduğunu da düşünmektedir. Dolayısıyla Hobbes'un felsefesinin, natüralizme ilişkin nitelikler barındırmasının yanı sıra materyalizme ilişkin nitelikleri de kapsadığı ileri sürülebilir (Gökberk, 1985:282; Duncan, 2019; Cevizci, 2013:98). Öbür taraftan Hobbes tıpk1 Bacon gibi, bir nominalist olduğunu Leviathan eserinde açıç̧a ifade etmiştir (Zabunoğlu, 1959:222-223; Duncan, 2019; Cevizci, 2013:106). Hobbes'a göre insanın sözcüklerle, diğer bir deyişle nesnelere verdiği adlandırmalarla oluşturduğu hakikatlerden başka bir hakikat bulunmamaktadır. Bu bakımdan Hobbes, dünyada isimler dışında evrensel bir şey olmadığını ve hakikatin sözcüklerin içinde bulunduğunu ileri sürmektedir. Böylece Hobbes'un felsefesinde düşüncenin, onu belirleyen sözcüğe ya da kavrama indirgenmekte olduğunu ifade etmek mümkündür (Ağaoğulları vd., 1994:178-176; Martinich, 2010:149; Cevizci, 2013:106).

Hobbes'un ampirist mi, yoksa rasyonalist mi olduğuna dair soruya ise terimlerin tanımlanış şekline göre cevap vermek mümkündür (Martinich, 2010:151). Öyle ki, bir önermede yer alan ad niteliğindeki tüm sözcüklerin

32 Aristotelesçi dünya görüşüne göre durgunluk (sükûnet) var olan her șeyin doğal hali olarak görülmektedir. Aristoteles'e göre insan ve diğer tüm varlıklar "hareket etmeyen hareket ettiricinin" durgunluğunu özlemektedir. Ancak Hobbes'un düşüncelerinden etkilendiği Galileo, doğal durumun hareketsizlik değil, hareket olduğunu ileri sürmektedir. Hatta bu hareket, sadece yeryüzündeki cisimler için değil, yeryüzünün kendisi içinde, güneş etrafında gerçekleştirilen bir hareketi kapsamaktadır. Hobbes ise Galileo'dan bir adım daha ileri giderek, insan da dâhil olmak üzere cisimlerin hareketlerinden başka bir şey olmadığını ileri sürmüştür (Cevizci, 2013:111).

33 Örneğin Hobbes’a göre, Grek felsefesi tamamıyla yararsız bir uğraştır (Cevizci, 2013:97).

34 Hobbes'a göre tanrı bile bir doğal nedendir, doğal nedenlerin en üstünüdür. Bu anlayışından ötürü Hobbes kimilerince, tehlikeli bir ateist olarak adlandırılmıştır (Martinich, 2010:143; Gökberk, 1985:282). 
duyuma kadar izinin sürülebilmesinin gerekli olduğunu iddia etmesi bakımından, ampiristtir. Diğer yandan terim, bilimsel önermelerin ampirik olgulara dayalı bildirimler olduğu anlamına geliyorsa, ampirist değildir. Benzer şekilde Hobbes, tüm bilimsel bilgilerin zorunlu olduğunu savunması bakımından rasyonalist iken, terim bazı bilimsel önermelerin analitik olmadığı anlamına geliyorsa, rasyonalist değildir (Martinich, 2010:151; Cevizci, 2013:85; Bektaş, 1993:179).

\subsubsection{Politik Devrim: Hobbes ve İngiliz İç Savaşı}

17. Yüzyılın, İngiltere tarihinde çok önemli bir döneme denk düştüğ̈̈ ifade edilebilir. Bu dönemde İngiltere'de meydana gelen dönüşümün; siyasal devrimden ekonomide, dinde ve başka birçok alanda yaşanan devrimlere kadar hayatın bütününü kapsar nitelikte bir dönüşümü içermekte olduğu belirtilebilir ${ }^{35}$ (Hill, 2016:13-17; Tannenbaum ve Schultz, 2006:236; Gökberk, 1985:281; Bektaş, 1993:179). Bu kapsamda yaşanan çatışmalar, hükümranlık için verilen bir mücadele olarak tanımlanabilir. Daha önce de belirtildiği üzere, bir yanda kral diğer yanda mülk sahiplerinin temsilcisi konumundaki parlamento, kimin egemen güç olacağı konusunda birbiriyle kanlı bir mücadele içerisine girmiştir (Hill, 2016:86; Tannenbaum ve Schultz, 2006:237).

İngiltere tarihinde bir kralın ilk defa parlamento tarafından idam edilmesi ile sonuçlanan bu iç savaş sürecinin kökenlerini, İngiltere Kral ve Kraliçeleri'nin kendilerini belli yükümlülükler altına sokan ve karşılarında bir parlamento olmasını kabul ettikleri 1215 tarihli Magna Carta'ya kadar götürmek mümkündür (Ağaoğulları vd., 1994:164). Bu bağlamda kırılma noktasının, hiç evlenmemiş ve çocuk sahibi olmamış olan I. Elizabeth'in 1603 'teki ölümü sonrasında, hanedanlığı Tudor Hanedanı'ndan devralan Stuart Hanedanı'na mensup hükümdarların, mutlak monarşi kurma arzuları olduğu ifade edilebilir (Ağaoğulları vd., 1994:165; WiesnerHanks, 2009:457).

1603 yılında tahta çıkan Stuart hanedanlığından I. James, henüz İskoçya kralı iken krallıktan ne anladığını açıkça dile getirmiş ve hiçbir sınır tanımayan mutlak monarşi düşüncesini savunmuştur. Bu bakımdan I. James kralın erkinin tanrıdan geldiğini, bütün kararları alan ve yasaları yapan kral karşısında parlamentonun ise hiçbir hakkının bulunmadığını ileri sürmüştür (Ağaoğulları vd., 1994:165-166; Wiesner-Hanks, 2009:457). Krallık iktidarını tanrısal kaynağa bağlayan bu görüş, kralların kararlarının tartışma konusu yapılmasına karşı çıkmış ve kralların yönetimlerinden dolayı yalnızca tanrıya karşı sorumlu olabileceği inancına dayanmıştır (Ağaoğulları vd., 1994:166). Yönetmek konusunda kralı önceleyen bu mutlak görüşe sahip olan I. James, vergi konusunda kendisine zorluk çıkaran parlamentoyu 1611 yılında dağıtmış ve 10 yıl boyunca toplanmasını engellemiştir. 1621 yılında yeniden topladığı parlamentoyu da kendi istediği şekilde yönlendiremeyince kısa sürede fesheden kral, oğlu I. Charles'a bu güçlükleri adeta miras bırakmıştır (Ağaoğulları vd., 1994:166-167; Wiesner-Hanks, 2009:459).

Özellikle 1625 yılında tahta geçen Kral I. Charles döneminde parlamentonun yayınladığı Haklar Bildirgesi (Petition of Rights), kral-parlamento arasındaki egemenlik mücadelesinde bir dönüm noktası olarak değerlendirilebilir. Bu bakımdan bildirge, kral tarafindan keyfi tutuklama ve parlamentonun onayı olmaksızın vergi toplanmasının yasa dışı olduğunu ilan etmesinin yanında, asker seferber etmeyi ve sıkıyönetimi yasaklamıştır. Bildirge sonrasında yaşanan karışıklıklar, Kral I. Charles tarafından 1629 yılında parlamentonun dağıtılmasına ve 1640 yılına kadar on bir yıl boyunca sürecek olan şahsi yönetimine yol açmıştır (Hill, 2016:2470; Ağaoğulları vd., 1994:167-168; Wiesner-Hanks, 2009:459). Ancak 1640 y1lında kral, iç karışıklıklar ve isyanlara karşı mücadele etme ve İskoç Presbiteryen ayaklanmalarını bastırma konusunda yaşadığı mali sorunlar sebebiyle pes etmek zorunda kalmış ve parlamento on bir yılın ardından tekrar toplanmıştır (Hill, 2016:27-140). Kısa Parlamento olarak bilinen bu parlamento, krala karşı katı tutumundan dolayı 18 gün içerisinde dağıtılmış olsa da, İskoçların İngiliz ordusunu yenilgiye uğratması sonucu I. Charles, aynı yıl parlamentoyu tekrar toplamak zorunda kalmış ve Uzun Parlamento olarak anılan parlamento toplanmıştır. Bu süreçte bir yandan parlamentonun, kralın gücünü sınırlayan kararlar almış olması; diğer yandan kralın, kişisel iktidarını mutlak bir

35 17. yüzyılda İngiltere içerisindeki bölünme birçok açıdan ele alınabilir. Ancak muhtemelen toplum içerisindeki bölünmelerin en büyüğü, din konusunda yaşanmaktadır. 16. yüzyılda Katolik öğretilere karşı kurulan ve resmi kilise haline gelen Anglikan (İngiliz) Kilisesi, hem Katolik öğretilerine karşı kendini savunmak hem de Katolik öğretilerine katı bir şekilde karşı olan ve Anglikan Kilisesi'nin gerçekte Katolik öğretilerini (kilise hiyerarşisi, gösterişli törenler benzeri) takip etmekte olduğunu ileri süren Püriten ve Presbiteryen yaklaşımlarına karşı mücadele vermek zorunda kalmıştır (Ağaoğulları vd., 1994:167; Tannenbaum ve Schultz, 2006:237; Wiesner-Hanks, 2009:458-459-460). Bu bakımdan din ögesinin İngiliz iç savaşı ve devriminin ideolojik temelini oluşturduğunu ileri sürmek mümkündür. Krala düşmanlık güdenlerin birleştikleri en önemli nokta, Anglikan Kilisesi’ne karş1 olmalarıdır. Ayrıca Püriten mezhebinin ateşli savunucularının, parlamento egemenliğini savunan siyasal muhalefetin odak noktası olduğu da savunulabilir (Ağaoğulları vd., 1994:167; Tannenbaum ve Schultz, 2006:237). 
biçimde sürdürmeye çalışmış olması İngiltere'yi bir iç savaşa sürüklemiştir (Ağaoğulları vd., 1994:168). Bu karmaşık sürecin sonunda ise, daha önce de belirtildiği üzere Kral I Charles, Oliver Cromwell'in Püriten mezhebinden oluşan tutkulu ve disiplinli ordusu tarafından yenilgiye uğratılmış ve 1649 yılında idam edilmiştir (Hill, 2016:149; Ağaoğulları vd., 1994:168-169; Tannenbaum ve Schultz, 2006:237; Wiesner-Hanks, 2009:462; Bektaş, 1993:179). I. Charles'in idamı sonrası İngiltere'de "Commonwealth" adı altında bir cumhuriyet kurulmuş ve "Lord Protector" Oliver Cromwell'in askeri diktatörlük yönetimi altında, 1660 yılına kadar krallık yönetimi ortadan kalkmıştır ${ }^{36}$ (Ağaoğulları vd., 1994:169; Hill, 2016:103-150).

$\mathrm{Bu}$ bağlamda İngiliz iç savaşının başlangıcında hemen hemen hiç kimsenin kralı devirmek ve idam etmek niyetinde olmadığını söylemek mümkündür. Ancak tarihteki diğer devrimlere benzer şekilde İngiliz iç savaşı ve devriminin de başlangıçta öngörülmeyen bir noktaya savrulduğu ifade edilebilir (Ağaoğulları vd., 1994:168169; Wiesner-Hanks, 2009:462). Bununla birlikte Cromwell'in 1658 yılındaki ölümünden sonra yerine geçen oğlu ülkeyi yönetememiş ve Hobbes'un Fransa'da matematik dersi verdiği II. Charles, tahta geçmesi için İngiltere'ye çağırılmıştır. II. Charles'in 1660 yılında tahta geçmesiyle birlikte, İngiltere'de 1649 yılında ortadan kaldırılmış olan krallık tekrar kurulmuştur. Krallığın yeniden kurulduğu bu döneme, daha önce de belirtildiği üzere restorasyon dönemi denmektedir ${ }^{37}$ (Ağaoğulları vd., 1994:170; Tannenbaum ve Schultz, 2006:237; Wiesner-Hanks, 2009:463).

Hobbes İngiliz iç savaşı yıllarını, daha önce de belirtildiği üzere İngiltere dışında geçirmiştir (Gökberk, 1985:281-286; Ağaoğulları vd., 1994:169; Bektaş, 1993:179). Başyapıtlarını, bir anlamda sürgün olarak adlandırılabilecek bu yıllarda kaleme almıştır (Ağaoğulları vd., 1994:169). Leviathan eseri, İngiltere'de iç savaşın sona ermesinden iki yıl sonra 1651 yılında hem sürgünde bulunduğu Fransa'da hem de İngiltere'de yayımlanmıştır. Eser hem İngiltere hem de Fransa'da çokça tepki almıştır. Hobbes'un eserinde, kralın tanrısal haklarına yer vermemesi, din ile ilgili görüşleri ve egemenliğin parlamentoda da olabileceğini kabul etmesi hem İngiliz kral yanlılarınca hem de Katolik Kilisesi ve Fransız yönetiminince tepkiyle karşılanmıştır. Eserin yayımlandığı tarihte Fransa'da olan Hobbes, kendini Fransa'da artık güvende hissetmemesi nedeniyle, 1652 yılında İngiltere'ye geri dönmek zorunda kalmıştır (Ağaoğulları vd., 1994:170).

\section{LEVIATHAN ESERININ SIYYASET VE YÖNETIM BILLIMLERI BAĞLAMINDA DEĞERLENDIRILMESI}

Çalışmanın bu bölümü, Leviathan eseri üzerinde gerçekleştirilen görece detaylı bir incelemeye ayrılmaktadır. $\mathrm{Bu}$ doğrultuda, öncelikle devletin ortaya çıkma nedenleri ve süreci ele alınmakta, sonrasında bir kere oluşturulmuş olan devletin işleyişine ve yönetimine ilişkin kavramlar ve kabuller incelenmektedir. Dolayısıyla eser hem Siyaset Bilimi hem de Yönetim Bilimi açısından ele alınmaktadır.

\subsection{Devletin Nedeni: Bireylerin Güvenliğinin Sağlanması}

Hobbes'un, hemen hemen herkes tarafindan yazarlık veriminin doruk noktası ve en önemli eseri olarak görülen 1651 tarihli Leviathan eseri (Cevizci, 2013:95; Güriz, 1955:301-302), toplamda 4 ana kısım ve 47 alt bölümden oluşmaktadır. Hobbes ilk kısımda insan doğasını ele almakta, din ve doğa ile alakalı konularda benimsediği fikirleri anlatmaktadır. Birinci kısımda algı, konuşma, akıl, bilim, değerler, erdemler gibi konuları tartışan Hobbes; doğa durumundaki insanı, doğa yasalarını ve toplumsal sözleşmeyi de ayrıntılı bir şekilde ele almaktadır. Başlı̆̆ "Devlet Üzerine" olan ikinci kısımda ise; devletin oluşturulması, varlık nedenleri, egemen gücün nitelikleri ve hakları, kamusal kuruluşlar, kamu görevlileri, devlet biçimleri gibi konuları açıklamaktadır. Eserin "Hıristiyan Bir Devlet Üzerine" başlıklı üçüncü kısmında, evrensel bir kilisenin var olabilmesinin neden mümkün olmadığını ele almaktadır. "Karanlık Krallığın Üzerine" başlık dördüncü kısımda ise Hobbes, Roma

36 Cromwell kralın idamından sonra 1653 yılında Uzun Parlamento olarak adlandırılan parlamentoyu da feshetmiştir. Fesih için askerleri ile birlikte parlamentoyu basıp yaptığı konuşma metni ve canlandırma videosu için bkz.: https://speakola.com/political/oliver-cromwell-speech-dismissing-rump-parliament-1653, (E.T.: 24.12.2019).

37 II. Charles 1660-1685 yılları arasında tahtta kalmıștır. Dolayısıyla 1679 yılında ölen Hobbes'un hayattayken gördüğü son kral II. Charles olmuştur. Hobbes öldükten sonra da İngiltere'deki dini ve sosyo-ekonomik çekişmeler devam etmiş ve başka önemli olaylar da yaşanmıştır. Bu çalışmada tarihsel dönemin koşullarının Hobbes üzerindeki etkisi ve Hobbes'un bu olaylar içerisindeki konumu incelendiğinden, ölümü sonrasında yaşanan gelişmeler ele alınmamaktadır. Ancak 17. yüzyılın sonuna gelindiğinde İngiltere'de "Şanlı Devrim" gerçekleşmiş ve egemenliğin parlamento ile monark arasında bölüşüldüğü açıkça kabul edilmiştir (Wiesner-Hanks, 2009:464). Hobbes'un ölümü sonrasında İngiltere'de yaşanan olayların detaylı şekilde incelendiği eserler için bkz.: Wiesner-Hanks, 2009; Hill, 2016. 
Kilisesi'nin eleştirisini gerçekleştirmektedir (Cevizci, 2013:96). Bu çalışma kapsamında, eserin özellikle ikinci bölümü ve gerek duyulduğunda da birinci ve üçüncü bölüme başvurulmaktadır. Nitekim Hobbes'un devlete ilişkin düşünceleri, anılan bölümlerde kapsamlı bir şekilde yazar tarafından ele alınmaktadır.

$\mathrm{Bu}$ bağlamda Hobbes Leviathan eserinde, devleti sözleşme ile oluşturulan yapay bir insan gibi görürken, egemenliği ona canlılık ve hareket kazandıran yapay bir ruha benzetmekte, kamu görevlilerini (yargıçlar ve diğer yargı/yürütme görevlileri) ise ona hareket kazandıran yapay eklemler olarak betimlemektedir. Hobbes'un bir doğal gövdedeki sinirlere benzettiği ödül ve cezalar ise, her eklem ve organa, bu durumda kamu görevlilerine, kendi görevini yaptıran yapay sinirler olarak betimlenmektedir (Hobbes, 2017:17). Dolayısıyla Hobbes'un Leviathan eseri üzerinden ortaya koyduğu devlet anlayışını çalışmak bir yandan devlet, egemenlik, meşruiyet, iktidar, otorite gibi kavramlar üzerinde durmayı gerektirirken, diğer yandan yönetim bilimine ilişkin kamusal kuruluşlar, kamu görevlileri, yetki, sorumluluk, tavsiye, danışmanlık gibi kavramlar üzerine bir okumayı da gerektirmektedir. Diğer bir deyişle Hobbes'un devlet anlayışı üzerine çalışmak, hem "olma" hem de "yapma" boyutlarıyla eserde devletin oluşumunun ve işleyişinin temel ilkeleri üzerinde durmayı gerektirmektedir ${ }^{38}$.

Toplumsal sözleşme kuramcıları ${ }^{39}$ arasında sayılan Hobbes; devletin var olmadı̆̆ durumu, doğa durumu ${ }^{40}$ olarak adlandırmaktadır (Hobbes, 2017:101). Hobbes'a göre insanlarda, yalnızca ölüm ile biten bir kudret arzusu vardır. İnsanlardaki bu arzunun nedeni ise, mevcut imkânların daha fazla şey elde etmeksizin güvence altına alınamayacağı düşüncesidir (Hobbes, 2017:81). Bu durum insanlar arasında, düşmanlığa ve savaşa neden olmaktadır (Hobbes, 2017:82). Nitekim Hobbes'a göre insanlar doğuştan eşittir. Bir insan, diğerinden bedenen ya da zihnen üstünmüş gibi görünse de; zayıf olduğu düşünülen her insan çeşitli yollarla, güçlü olduğu düşünüleni öldürmeye yetecek kadar güce sahiptir (Hobbes, 2017:99). İnsanlar arasındaki bu eşitlik durumundan güvensizliğin doğduğunu ifade eden Hobbes, anılan güvensizlik durumunun ise, insanları savaş durumuna soktuğunu ifade etmektedir (Hobbes, 2017:100).

İnsan doğasında üç temel kavga nedeni olduğunu ileri süren Hobbes, bunlardan ikincisi olarak saydığı güvensizliğin insanı, güvenliğini sağlaması ve kendisini koruması için şiddet kullanmaya ittiğini ifade etmektedir (Hobbes, 2017:101-217; Poggi, 2016:16-17). Devletin var olmadığı durumda, diğer bir deyişle doğa durumunda, insanların tamamını kontrol altında tutabilecek bir güç olmaması nedeniyle, herkesin herkese karşı daimi bir savaş durumu içerisinde yaşadığını belirten Hobbes, anılan savaş durumunda adalete aykırı hiçbir şeyin bulunmadığını ileri sürmektedir (Hobbes, 2017:101-102-103-114). Nitekim Hobbes'a göre doğa durumunda herkes yargıç olduğu için, suçlamaya ya da cezaya yer bulunmamaktadır (Hobbes, 2017:112-219).

Hobbes'un ortaya koyduğu anlayışa göre akıl, insanların ölüm korkusu ile yaşadıkları bu savaş durumdan kurtulabilmeleri için üzerinde mutabık kalabilecekleri doğa yasaları olarak adlandırılan barış şartlarını sunmakta ve teşvik etmektedir (Hobbes, 2017:103-202). Hobbes'a göre doğa durumunda insanların sahip olduğu doğal hak ise, insanın kendi güvenliğini sağlayabilmek için gücünü dilediği şekilde kullanabilmesidir. Bu bakımdan doğa yasası, insan aklı ile bulunan ve insanların güvenlik/korunma ihtiyacını olumsuz şekilde etkileyen şeyleri yapmasina yasak getiren genel ilkedir (Hobbes, 2017:103-104).

Bu bağlamda Hobbes, insan aklı ile keşfedilen doğa yasalarının ilki olarak, barışın sağlanması için insanların uğraş vermesi gerekliliği ilkesini ortaya koymaktadır. Ancak Hobbes’a göre anılan doğa yasasının, insanların sahip olduğu doğal hak kavramını kısıtlayıcı bir yanı bulunmaktadır (Hobbes, 2017:202). Nitekim daha önce de belirtildiği üzere doğal hak, insanların güvenliğini sağlamak ve korunmak için her yola başvurabileceğini onaylayan bir hak anlayışıdır (Hobbes, 2017:104). Hobbes'un ilk doğa yasası ile ilişkili olarak ortaya koyduğu

38 Burada kullanılan olma ve yapma sözcükleri, 2019-2020 eğitim ve öğretim yılı güz döneminde Ankara Üniversitesi Yönetim Bilimleri Bilim Dalı doktora programı bünyesinde Prof. Dr. Birgül Ayman Güler'in yürüttüğü Devlet Bilimi Metodolojisi dersinde, Güler'in kullandığı anlamda kullanılmaktadır.

39 Modern devlet düşüncesine temel oluşturmuş Toplumsal Sözleşme Kuramları, 17. yüzyıldan itibaren batıda gelişmiştir. Thomas Hobbes, John Locke ve Jean-Jacques Rousseau'nun öncülüğünü yaptığı Toplumsal Sözleşme Kuramları'na göre insanlar; (modern) devlet öncesinde, doğa durumu içerisinde yaşamaktadırlar. Toplumsal Sözleşme Kuramları'nın temsilcileri olan bu düşünürlere göre, devletin kuruluşunun arkasındaki tetikleyici neden, doğa durumunda yaşayan insanların üstesinden gelemediği korku ve güvenlikten yoksun olma hissidir (Heywood, 2015:31). Bu anlayışa göre devlet, insan aklının bir ürünüdür. Doğa durumunda yaşayan insanların, güvenlikten yoksun bu durumdan kurtulmak için aralarında gerçekleştirdikleri sözleşme, toplumsal sözleşme olarak adlandırılmaktadır. Nitekim Toplumsal Sözleşme Kuramları'na göre, devletin temelinde, anılan sözleşme yatmaktadır (Heywood, 2015:31). Bu bakımdan toplum sözleşmesi aracılı̆̆ıyla kurulan devlet, insanların barış ve güvenlik içerisinde yaşayabilmeleri amacıyla, her türlü tehdide karşı korunmaları anlamına gelmektedir (Goldstein, 2010:491).

40 Hobbes'un Leviathan eserinde tanımladığı doğa durumu, aslında bir tür şiddet ve hayat/mülkiyet kaybıyla karakterize edilebilecek olan İngiliz İç Savaşı'nı resmetmektedir (Tannenbaum ve Schultz, 2006:237-241). 
ikinci doğa yasası ise bireyin, her şey üzerindeki doğal hakkını diğer bireyler ile eş değer şekilde bırakması anlamına gelmektedir (Hobbes, 2017:104-105). İkinci doğa yasası olarak sayılan bu hak birakmanın, ya o haktan feragat etme/vazgeçme ya da o hakkı başka birine devretme şeklinde gerçekleşebileceğini belirten Hobbes, iki yoldan herhangi biriyle bırakılan hakkın, bırakıldığı kimselerce yararlanılmasına/kullanılmasına, hakkı bırakan kişice engel olmama yükümlülüğ̈̈ olduğunu ifade etmektedir (Hobbes, 2017:105). Öte yandan Hobbes, bütün hakların bırakılabilir/devredilebilir olmadığını da ileri sürmektedir. Ona göre hak bırakmak, özü itibari ile kişinin faydasına olmalıdır. Bu nedenle kişinin hak bırakması/devretmesi, kendi güvenliğini olumsuz etkilemeyecek şekilde gerçekleşmelidir (Hobbes, 2017:105-224).

Bu noktada Hobbes'a göre insanların karşılıklı olarak hak devretmesine, sözleşme denmektedir (Hobbes, 2017:105). Ancak doğa durumunda yapılan ve kişilerin birbirine karş1lıklı güvenine dayanan sözleşmeler, doğa durumunda tarafların üzerinde zorlayıcı bir güç olmaması nedeniyle taraflardan birinin makul şüphesi üzerine kolayca geçersiz sayılabilir. Devletin var olması durumunda ise, taraflar üzerinde zorlayıcı bir güç (devlet) olması nedeniyle o sözleşme geçerliliğini korur ve sözleşme tarafları sözleşmeye uymak durumundadırlar (Hobbes, 2017:109). Öte yandan Hobbes'a göre bir insanın, kendi güvenliğini tehlikeye atan ya da güvenliği tehlikeye girdiğinde kendisini savunmamasını şart koşan hiçbir sözleşme, hiçbir durumda geçerli değildir (Hobbes, 2017:111-168-219).

Hobbes doğa yasaları içerisinde, insanların yaptıkları sözleşmelere sadık kalması gerekliliğini üçüncü doğa yasası olarak ortaya koymaktadır. Ona göre insanların sözleşmelere sadık kalmamaları durumunda, herkesin her şey üzerinde sahip olduğu doğal hak devam edecek ve insanlık savaş durumundan çıkamayacaktır (Hobbes, 2017:113). Bu bakımdan Hobbes'a göre doğa durumunda yaşayan insanlar, sözleşmenin yerine getirileceğinden ve ona uyulacağından emin olamayacakları için, ancak insanları sözleşmeye uygun hareket etmeye zorlayacak bir devletin kurulması ile birlikte sözleşmelerin geçerliliğinden söz edilebilmektedir (Hobbes, 2017:114-115133).

Kılıç gücü olmadığında, diğer bir deyişle insanlar üzerinde güç/zor kullanabilen bir devletin var olmadığı durumlarda, ne doğa yasalarının ne sözleşmelerin ne de insanların güvence altında olduğunu ifade eden Hobbes, anılan durumun insanları sonuçları oldukça yıkıcı olan savaş durumundan kurtaramayacağını ifade etmektedir (Hobbes, 2017:133; Kössler, 2003:18). Bu bağlamda Hobbes doğa yasaları ile ulaşılamayan güvenlik durumunun, devletin kurulması ile sağlanabileceğini savunurken, temelde devletin amacının bireylerin güvenliğini sağlamak olduğunu ortaya koymaktadır (Hobbes, 2017:133-197-219-226-249; Kössler, 2003:21; Pierson, 2004:7). Nitekim ona göre, insanların hayatları boyunca sahip olmayı arzuladıkları güvenlik olgusu, devlet olmaksızın var olamamaktadır (Hobbes, 2017:134-202).

Devleti, insanlar arasında gerçekleştirilen ve herkesin doğal hakkını (kendi güvenliğini sağlamak amacıyla, istediği zaman şiddet kullanabilme özgürlüğünü) kendi arzusu ile sınırlandıran sözleşme kavramı üzerinden açıklayan Hobbes, ortak barış ve güvenliğin yalnızca hak devri sonucu oluşturulan bu devlet vasıtasıyla sağlanabileceğini belirtmektedir (Hobbes, 2017:136-147; Goldstein, 2010:490). Devletin hangi şartta olursa olsun, yokluğu kadar zararlı olamayacağını ileri süren Hobbes egemeni, ona tabi olan diğer insanların üzerinde konumlandırmakta ve bu yolla devleti, toplumdan üstün görmektedir (Hobbes, 2017:138-139-143-144-145-161162; Goldstein, 2010:490; Kössler, 2003:18-19). İnsanlar arasında gerçekleştirilen sözleşme yoluyla kurulan devletin ve egemenliğin, bölünemez ve mutlak olduğunu ileri süren Hobbes, devleti ortak güvenliğin ve barışın sağlanması hususunda, gerekli araçlarının kullanılması ve güvenliğe ilişkin ne yapılması gerektiğine karar vermesi bağlamında tek belirleyici olarak görmektedir (Hobbes, 2017:140-142-143-144-146-167-243). Öte yandan Hobbes'a göre hem savaş hem de barış dönemlerinde egemen; danışmanların, bakanların, yargıçların ve memurların seçimine tek başına karar vermektedir. $\mathrm{Bu}$ seçim hakkı, egemenliğin bir parçası olarak görülmektedir. Ayrıca egemen, orduya (militia) başkomutanlık etmekte, yargı yetkisini ve yasa yapma gücünü tek başına kullanmakta ve düşünceleri kendisi yönetmektedir (Hobbes, 2017:142-143). Dolayısıyla, Hobbes'a göre sözleşme yoluyla oluşturulan devletin, şiddet kullanımına ilişkin eylemler ve araçlar üzerinde tekel bir konumu bulunmakta ve bu tekel konumu, toplumun genel çıkarına uygun olmaktadır (Kössler, 2003:18-20; Wimmer, 2003:1).

Hobbes her ne kadar egemeni, ona sözleşme ile tabi olan insanlar tarafından eleştirilemez, cezalandırılamaz, vazgeçilemez mutlak bir güç olarak görse de, uyrukların yerine getirmesi gereken bu yükümlülükler, yalnızca egemenin uyruklarının güvenliğini sağlayabilecek kapasiteye sahip olması ile sınırlı olmaktadır. Bir diğer deyişle, buradaki itaatin amacı korunmadır ve bu korunma ortadan kalkarsa, uyruklar egemene itaat etmeme hakkına sahip olabilmektedirler. Böyle bir durumda insanlar, doğa durumunda sahip oldukları, herkesin kendi güvenliği ve savunmasını sağlama hakkına sahip olurlar (Hobbes, 2017:138-139-140-171-219-249). 
Hobbes'a göre uyruklar, egemenin yasak koymadığı her şeyi yapabilirler. Bir diğer deyişle uyrukların sahip olduğu en büyük özgürlük, yasaların sessizliği ile ilişkilidir. Nitekim Hobbes'a gore (2017: 165-170) uyruk, egemenin yasa ile düzenlemediği her konuda arzuladığı gibi davranmakta özgürdür. Ancak Hobbes'a göre devlet, güç kullanabilme tekeli olduğundan, özellikle uyrukların kendi aralarında kurdukları savunma amaçlı oluşumlar, gereksiz ve yasadışıdır (Hobbes, 2017:181-182). Nitekim Hobbes'a göre, devletin koruması altında yer alan insanların güvenliklerinin sağlanması için, devlet dışında herhangi başka bir korumaya ihtiyacı bulunmamaktadır (Hobbes, 2017:182). Bu bağlamda Hobbes'a göre, tebaanın üyelerinin kişisel anlamda şiddet kullanması istenen bir durum olmamakla beraber, toplumsal sözleşme yoluyla kurulan devletin temel amacina ve varoluşsal nedenine de aykırıdır (Hobbes, 2017:254; Kössler, 2003:19).

Özetle, Toplumsal Sözleşme Kuramları düşünürlerinden Hobbes'a göre sözleşme yapılmasının amacı ve devletin varoluşsal nedeni, bireylerin güvenliğinin sağlanmasıdır. Bu bağlamda sözleşme sonucu oluş(turul)an devlet, üyesi olan bireyleri hem dışarıdan gelebilecek olası tehditlere hem de devlet/toplum içerisinde birbirlerine karşı koruma ve güvenliklerini sağlama fonksiyonunu yerine getirmektedir. Dolayısıyla insanlar arasında gerçekleştirilen toplumsal sözleşmeye göre bireylerin güvenliği, egemen güç olan devlet tarafindan sağlanmaktadır. Devletin, güvenliğin sağlanmasına ilişkin bu fonksiyonu, devletin hem yetki hem de sorumluluk alanı içerisinde yer almaktadır. ${ }^{41}$

Hobbes'un ortaya koyduğu devlet anlayışına göre devlet ile uyruklar arasındaki ilişki, karşıllıklı hak ve yükümlülükler üzerinden tanımlanmaktadır. Bu kapsamda toplumsal sözleşme sonucu oluş(turul)an devletin, sözleşme tarafı bireylerin güvenliğini sağlaması gerekirken, bireylerin de devletin güvenlik fonksiyonunu yerine getirirken koyduğu kurallara uyması gerekmektedir. Bu bağlamda bireylerin toplumsal sözleşme üzerinden devlete, güvenlik için özgürlüklerini kısıtlayabilme hakkı verdiği ifade edilebilir. Nitekim bireylerin devlete verdikleri bu hak sonucunda devletin uyruklarının güvenliğini sağlaması, devletin meşruiyetini de ifade etmektedir.

\subsubsection{Devlet Biçimleri: Monarşi, Demokrasi ve Aristokrasi}

Hobbes'un toplumsal sözleşme yoluyla oluşturulan devlet ve egemenliğe ilişkin düşüncelerini bu şekilde özetlemek mümkün iken, devlet biçimlerine ilişkin açıklamaları üzerinde de durulabilir. Hobbes'a göre, toplumsal sözleşme yoluyla kurulmuş sadece üç çeşit devlet bulunmaktadır (Hobbes, 2017:145-150). Bu üç çeşit devlet arasındaki fark, egemenliğin kimin elinde bulunduğundan kaynaklanmaktadır. Buna göre egemenliğin tek bir kişide ya da bir heyette olması bakımından devlet biçimleri monarşi, demokrasi ve aristokrasi isimlerini almaktadır (Hobbes, 2017:146). Egemen temsilci bir kişi olduğunda monarşi, bir araya gelen herkesten oluşan bir heyet olduğunda demokrasi (halk devleti) ve toplumun sadece bir kesiminin heyeti olduğunda ise aristokrasidir (Hobbes, 2017:146). Hobbes'a göre egemenlik bölünemeyeceği için onu ya bir kişi ya bir grup ya da herkes elinde tutabilmektedir. Bu nedenle Hobbes tarafından yalnızca anılan üç çeşit devlet biçiminin var olduğu ifade edilmektedir ${ }^{42}$ (Hobbes, 2017:146).

$\mathrm{Bu}$ noktada monarşi ile diğer egemen meclisleri kıyaslama işine girişen Hobbes, monarşiyi birçok açıdan egemen meclislere üstün tutmaktadır. Hobbes'a göre monarşide hükümdarın özel çıkarı ile kamu çıkarı özdeştir. Aynı özdeşlik meclis egemenliklerinde söz konusu değildir (Hobbes, 2017:144-7). Monarşide hükümdarın istediği zaman istediği kişiden tavsiye alması, diğer bir deyişle iyi danışmanlardan faydalanması mümkün iken; egemen meclislerde, yalnızca en başından beri orada bulunan ve bilgiden çok servetleri ile ön planda olan kişilere başvurulabilir. Ayrıca meclislerin kalabalık olması dolayısıyla, gizlilik gerektiren görüş almalar hiçbir şekilde meclislerde gerçekleşemez (Hobbes, 2017:147-148). Hobbes'a göre bir monark, insan doğasından kaynaklanan çelişkiler haricinde hiçbir çelişkiye tabi değil iken; egemen meclisler insan doğasının getirdiği çelişkilerin yanında, kalabalıktan kaynaklanan çelişkileri de barındırmaktadır. Ayrıca bir monark, kıskançlık ve çıkarlar nedeniyle kendi kendine anlaşmazlığa düşemez iken; egemen meclisler aynı anlaşmazlığa rahatça düşebilir ve hatta bu anlaşmazlık, iç savaşa bile neden olabilir (Hobbes, 2017:148).

41 Hobbes'a göre toplumsal sözleşme yoluyla uyruklar, devleti bütün eylemlerinde yetkili kılmaktadır (Hobbes, 2017: 136-137-139140). Bu bakımdan oluşturulan mutlak egemenlik, sınırsız yetkiye sahiptir (Hobbes, 2017:173).

42 Hobbes'a göre tiranlık ve oligarşi, monarşi ve aristokrasinin farklı adlarından başka bir şey değildir. Bu bakımdan tiranlık monarşinin ve oligarşi aristokrasinin kötülenmiş halleridir. Diğer bir deyişle monarşiden memnun olmayanlar ona tiranlık, aristokrasiden memnun olmayanlar ona oligarşi demektedirler (Hobbes, 2017:146). 


\subsubsection{Zor ile Kurulmuş Devletin Benzerlikleri ve Farkı}

Hobbes'un monarşi ile egemen meclisler arasındaki kıyaslamalarını bu şekilde özetlemek mümkün iken, zorla kurulmuş bir devletin ne olduğu ve sözleşme ile kurulmuş bir devlet ile arasında fark olup olmadığı üzerinde de durulabilir. Hobbes'a göre zorla kurulmuş bir devlet, egemen gücün zorla ele geçirildiği vakit var olmaktadır. Ele geçirilen yerdeki insanların çoğunluğu ölüm ve/veya esaret korkusundan dolayı monarkın ya da meclisin bütün eylemlerini kabul ettiklerinde, egemen güç zorla ele geçirilmiş demektir (Hobbes, 2017:155).

Hobbes'a göre zorla kurulmuş bu devlet ile sözleşmeyle kurulmuş devlet arasındaki tek fark, insanların korktuğu kişinin farklı olmasıdır. Buna göre, sözleşmeyle kurulan devletlerde insanlar birbirinden korktuğu için devleti kurarken, zorla kurulmuş devletlerde insanlar, korktukları kişiye boyun eğmektedirler (Hobbes, 2017:155).

Her iki devlette de egemenlik hakları ve sonuçları birbirinin aynısıdır. Hem sözleşmeyle hem de zor yoluyla kurulmuş devletlere ilişkin egemenlik hakları şu şekilde sıralanabilir: egemenin gücü kendi rızası olmadan başka birine devredilemez; egemen gücünden feragat edemez; egemen uyrukları tarafından haksızlık yaptığı gerekçesi ile suçlanamaz ve cezalandırılamaz; barış için neyin gerekli olduğunun karar vericisi ve düşünceler ile anlaşmazlıkların yargıcı egemendir; egemen tek yasa koyucudur; barış ve savaş zamanlarına ve gerekçelerine egemen karar verir; bakanların, yüksek devlet görevlilerinin, danışmanların, komutanların ve bütün diğer memurların seçimine egemen karar verir; ödülleri, cezaları, paye ve unvanları dağıtma hakkı egemendedir (Hobbes, 2017:134-137-138-143-155-156-161-165).

\subsection{Düzenli, Bağımlı ve Siyasal İnsan Sistemleri: Kamusal Kuruluşlar}

Hobbes bir devletin ortaya çı(arıl)masından (doğuşundan), biçiminden ve gücünden bahsettikten sonra, devletin diğer kısımlarını da bir incelemeye tabi tutmaktadır (Hobbes, 2017:173). İlk olarak, bir konuda ya da bir işte birleşmiş olan insanların oluşturduğu sistemlerden bahseden Hobbes bu sistemleri, düzenli ve düzensiz olmak üzere ikiye ayırmaktadır. Bir kişi ya da meclisin, tümünün bir temsilcisi olarak atandığı sistemleri düzenli sistemler olarak adlandırırken, başka her türlü sistemi düzensiz olarak görmektedir. Düzenli sistemleri ise mutlak ve bağımsız olanlar ${ }^{43}$ ile bağımlı olanlar olmak üzere ikiye ayıran Hobbes, bağımlı olanları da kendi içerisinde siyasal ve özel olanlar olmak üzere ikili bir ayrıma tabi tutmaktadır. Hobbes bu noktada siyasal olanları (düzenli, bağımlı), kamusal kuruluşlar ve tüzel kişiler olarak saymaktadır. Buna göre kamusal kuruluşlar ve tüzel kişiler denilen siyasal kuruluşlar, devletin egemen gücünden alınan yetki ${ }^{44}$ sayesinde, diğer bir deyişle kamusal yetki ile kurulmaktadırlar (Hobbes, 2017:173-180). Bu yönüyle kamusal kuruluşlar, egemen güce bağlı ve ona tabi olan kuruluşlardır (Hobbes, 2017:176-180).

Hobbes'a göre kamusal kuruluşların türleri neredeyse sonsuzdur. Nitekim kamusal kuruluşlar, sadece kurulma amaçları olan çeşitli faaliyetlerle değil, aynı zamanda zaman, yer, üye sayıları ve tabi oldukları sınırlamalar bakımından da çeşitlenmektedirler (Hobbes, 2017:176). Ayrıca kamusal kuruluşların kararlarına, uyruklar tarafindan itiraz edebilmenin hem yasal hem de mümkün (hatta kimi durumlarda gerekli) olduğunu ifade eden Hobbes, aynı itirazın egemen güce yapılamayacağını belirtmektedir. Nitekim Hobbes'a göre, egemen tarafından emredilen her şey, gerekçelerini o emirde bulundurmaktadır (Hobbes, 2017:176).

Hobbes her ne kadar kamusal kuruluşların çeşitleri bakımından neredeyse sonsuz olduğunu belirtse de onları, üç çeşit kamusal kuruluş altında incelemektedir. Bunlardan ilki olan eyalet ${ }^{45}$, koloni veya şehrin yönetimi için kamusal kuruluşlar, egemen tarafından yönetimle görevlendirilmiş kamusal kuruluşlardır (Hobbes, 2017:176). $\mathrm{Bu}$ kuruluşların yetkileri resmi talimatla sınırlıdır ve egemen için, onun emri altında ilgili yerin yönetimine

43 Hobbes'a göre yalnızca devletler böyledir. Nitekim devletler mutlak ve bağımsız olup, kendi temsilcilerinden başka hiçbir güce tabi değildir (Hobbes, 2017:173).

44 Hobbes'a göre herhangi bir eylemi yapma hakkına yetki denilir. Bir işin yetkiyle yapılması ise, hak sahibinin verdiği izin ve ruhsat ile işin yapılması anlamına gelmektedir (Hobbes, 2017:126). Daha önce belirtildiği üzere, sınırsız yetki yalnızca egemen güçtedir (Hobbes, 2017:173).

45 Egemenin ikamet etmediği ancak vekâleten yönettiği ülkelere eyalet denmektedir (Hobbes, 2017:177). Nitekim eyalet kelimesinin İngilizce karşılığı olan province kelimesinin anlamları içerisinde "iş, görev, sorumluluk alanı, vb." de bulunmaktadır. Kavramının bu anlamlarına ilişkin ayrıntılı bilgi için bkz.:

https://dictionary.cambridge.org/dictionary/english/province; 17.12.2019. 
yönelik faaliyetleri gerçekleştirmektedirler (Hobbes, 2017:177-178). İkinci olarak incelediği kamusal kuruluş ise ticaretin düzenlenmesi için kamusal kuruluşlardır (Hobbes, 2017:178). Adından anlaşılacağı üzere bu kamusal kuruluşlar, iç ve dış ticaret işleri ile uğraşan kamusal kuruluşlardır (Hobbes, 179-180). Son olarak üzerinde durduğu kamusal kuruluş çeşidi ise, egemene tavsiye veren kamusal kuruluşlardır (Hobbes, 2017:180). $\mathrm{Bu}$ çeşit kamusal kuruluşlar, insanların veya ticaretin yönetimi için oluşturulmuş kuruluşlardır. Anılan kuruluşlar, sürekli ya da yazılı olarak belirlenmiş belirli bir süre için var olabileceği gibi, egemen tarafindan gerçekleştirmeleri emredilen faaliyetlerin doğası bakımından süreleri kendiliğinden sınırlanmış kamusal kuruluşlar olarak da var olabilmektedirler. Faaliyetlerinin niteliği bakımından geçici süre ile kamusal kuruluş olarak var olan bu oluşumlar, egemenin (egemen monark ya da egemen meclis) isteğini (iyi yasalar yapmak ya da başka bir amaç için tavsiyede bulunmalarını istemek gibi) yerine getirdikten sonra dağılmakta ve var oluşları son bulmaktadır (Hobbes, 2017:180).

Hobbes'a göre bütün kamusal kuruluşlarda temsilcinin yetkisi, egemen gücün belirlediği şekilde sınırlıdır. Nitekim ortaya koyduğu egemenlik anlayışına göre sınırsız yetki, yalnızca mutlak egemenlik ile var olabilmektedir. Bu bakımdan uyruklardan oluşan bir kamusal kuruluşa, ilgili her konuda tam yetkilere sahip mutlak bir temsilciye sahip olabilme hakkının verilmesi, devletin ilgili kısmının yönetiminin terkedilmesi anlamına gelmekte ve devletin varoluşsal nedeni olan barış ile güvenliğin sağlanması ilkesine tezat şekilde egemenliğin bölünmesine denk düşmektedir (Hobbes, 2017:174).

Bir kamusal kuruluşun temsilcisine verilen yetkinin sınırları, iki şeyce belirlenmektedir: egemenin fermanı veya yazısı, devletin yasaları. İlk olarak (düzenli, bağımlı, siyasal) kamusal kuruluşlar hakkında; bunların işleri, zamanları ve yerlerini sınırlayan birçok yazılı sınırlama bulunmaktadır. Yazılı olmaları sayesinde akılda tutulabilmelerini kolaylaştıran bu çok çeşitli yazılı sınırlamalar, mühürlü ya da otoritenin benzeri kalıcı işaretleriyle onaylanmış olarak aleni şekilde ulaşılabilir olmalıdır. Böylece bu yazılı sınırlamalar, insanlar tarafından ulaşılabilir hale gelmeli ve sınırlara ilişkin öğretici olma amacını yerine getirmelidir (Hobbes, 2017:174). Öte yandan sınırlamaların yazılı olarak öğretilmesi ve anlatılması oldukça zor ve kimi zaman neredeyse imkânsız olduğu için, toplumsal sözleşmenin tarafi olan bütün uyruklarca bilinen olağan yasalar, egemenin bir yazı ile kural koymadığı ve sınırlandırmadığı tüm durumlarda kamusal kuruluşun temsilcisinin yasal olarak yapabileceği şeyleri içermeli ve belirlemelidir (Hobbes, 2017:174).

Hobbes kamusal kuruluşun sınırlamalar çerçevesinde belirlenen yetkilerini kullanan temsilcilerin, ister tek bir kişi ister bir meclis olsun, yetkisiz ya da yetkili olarak gerçekleştirdiği işlemlerin niteliğini ve ortaya çıkan durumları ve sonuçları da ayrıntılı olarak ele almaktadır. Bu bağlamda Hobbes'a göre, temsilci bir kişi olduğunda ve yetkisiz işlemler yaptığında, diğer bir deyişle yetki yazısında veya yasalarda verilen bir yetkisi olmaksızın kamusal kuruluşun kişiliğinde işlemler gerçekleştirdiğinde, yaptığı işlemler/işler kendi işi olarak değerlendirilir. Bu bakımdan temsilci, sınırların ötesine geçmesinden ötürü yalnızca kendi kişiliğini temsil eder hale gelmektedir. Ancak temsilci kişinin sınırlamalar dâhilinde, diğer bir deyişle egemenin ya da yasaların koyduğu sinırlamalara uygun şekilde gerçekleştirdiği işlemler, egemenin işlemleri olarak görülmektedir (Hobbes, 2017:174). Hobbes'a göre temsilcinin bir meclis olduğu durumlarda, gerçekleştirilen işlem yalnızca onu kabul edenlerin işlemi olarak görülmektedir. Bu bağlamda, kamusal bir kuruluşta temsilci konumundaki meclisin yetkilerinin sınırlarını belirleyen belgeler ya da yasalar tarafından öngörülmemiş bir işlemi/kararı, yalnızca işlemin uygulanmasına yönelik kararın alınmasına olumlu oy veren üyelerin işlemi olarak kabul edilmekte ve buna göre muamele edilmektedir (Hobbes, 2017:174-175). Bu bakımdan anılan kararın alınmasında aksi yönde oy kullanan ya da hazır bulunmayan kişilerin, kararın alınmasından ve işlemin gerçekleştirilmesinden kaynaklanan sorunlardan sorumlu olmadığı ifade edilebilir. Ayrıca Hobbes'a göre çoğunluk tarafından oylanan ve onaylanan, dolayısıyla temsilci meclisin bir işlemi olan bu durumda, özellikle kararın ve işlemin bir suç teşkil etmesi durumunda, ya meclis feshedilmeli ya da yetki belgesi iptal edilmelidir. $\mathrm{Bu}$ yaptırımlar haricinde Hobbes meclisin, sınırlamaların ötesine geçen anılan karar ve işlemine ortaklık etmeyen masum üyelerinin pay sahibi olmadığı bir mal varlığına sahip olması durumunda, meclise para cezası verilebileceğini de belirtmektedir (Hobbes, 2017:175).

\subsection{Bir Devletin Organik Kısımları: Kamu Görevlileri}

Hobbes kamusal kuruluşları, düzenli siyasal bağımlı sistemler başlığı altında ele aldıktan ve dolayısıyla bir devletin benzer kısımlarından söz ettikten sonra, bir devletin organik kısımları olarak nitelendirdiği kamu görevlilerinden $^{46}$ (memur) de bahsetmektedir (Hobbes, 2017:17-184). Hobbes’a göre bir kamu görevlisi,

46 Siyaset Bilimi alanında, kamu görevlisinin tanımını yapma işine girişen ilk düşünürlerden biri Hobbes’tur (Güler, 2005:66). 
egemen monark ya da egemen meclis tarafından belirli bir alanda devletin kişiliğini temsil etmek yetkisi ${ }^{47}$ ile istihdam edilen kişidir (Hobbes, 2017:76-184). Bu bakımdan Hobbes'un kamu görevlisi tanımı, devletin kişiliğini temsil etmek ve egemen tarafından istihdam edilmek ilkelerine dayanmaktadır. Bu bağlamda bir egemen uyruklarından bazılarına, onları onurlandırmak maksadıyla bir unvan, makam, görev ve iş verebilmektedir $^{48}$ (Hobbes, 2017:74-76).

Kimin, hangi işler ve hizmetler bağlamında kamu görevlisi kategorisi içerisinde yer alabileceğine açıklık getiren Hobbes öncelikle, egemen olan monark ya da meclisin iki kişiliği temsil ettiğini belirtmektedir. Buna göre egemen (monark ya da meclis), biri doğal diğeri kamusal olan iki kişiliği temsil etmekte, diğer bir deyişle biri doğal diğeri kamusal olan iki sıfata sahip olmaktadır. Kamusal kişilik egemenin, devletin kişiliğine büründüğ̈̈ durumdur. Bu bağlamda bir egemene doğal kişiliği ile ilgili konularda doğal yoldan hizmet eden kişiler (örneğin meclisin rahatlığını sağlamak amacıyla hizmet eden kapıcılar, bekçiler ve diğer memurlar ile bir monarkın konutunun kâhyaları, hazinedarları gibi görevliler), kamu görevlisi kategorisine girmemektedir. Nitekim Hobbes'a göre kamu görevlileri egemene, yalnızca kamu(nun) yönetimi kapsamında hizmet eden görevlilerdir (Hobbes, 2017:184).

Hobbes, kamu görevlilerine ilişkin bir sınıflandırma da yapmaktadır. Sınıflandırma içerisinde ilk olarak sayılan kamu görevlileri, genel yönetimden sorumlu kamu görevlileridir. Bunlar, bir ülkenin tamamının veya yalnızca bir kısmının genel yönetim sorumluluğunun, egemen tarafından verildiği kamu görevlileridir. Kendilerine genel yönetim sorumluluğu verilen bu yöneticiler/kamu görevlileri (valiler, vekiller gibi), egemenin iradesine dayanmayan hiçbir hakka sahip değillerdir. ${ }^{49}$ Ayrıca uyruklar, kamu görevlisinin/yöneticinin, egemenin buyrukları ile çelişmeyen uygulama, karar ve emirlerine itaat ile yükümlüdür (Hobbes, 2017:184).

Kamu görevlileri sınıflandırmasında sayılan ikinci grup kamu görevlileri ise, askeri ve ekonomi gibi uzmanlığa dayanan özel yönetim işlerinden sorumlu kamu görevlileridir (Hobbes, 2017:184). Bu kamu görevlileri, yurt içinde veya dışında özel bir işten sorumlu olarak çalışırlar. İlk olarak yurt içinde hazine ile ilgili olarak vergilerin, harçların, kiraların, para cezalarının ve ilgili diğer kamusal gelirlerin tahsil edilmesi, toplanması gibi faaliyetleri egemen adına gerçekleştiren kamu görevlileri, bu sınıflandırma içerisinde yer almaktadır (Hobbes, 2017:185). İkinci olarak ordu (militia) içerisinde kaleleri, limanları, silahları korumak ile askerlerin toplanması, ödemelerinin yapılması ve yönetilmesi gibi sorumluluk ve yetkilere sahip olanlar da, anılan sınıflandırma içerisinde yer alan kamu görevlileridir (Hobbes, 2017:185). Dolayısıyla bu grupta yalnızca komuta yetkisine sahip olan askerler, kamu görevlileridir ${ }^{50}$ (Hobbes, 2017:185).

Üçüncü sıradaki kamu görevlileri, halkın eğitiminde görev alan kamu görevlileridir. Bunlar öğretmek yetkisine ya da başkalarının, halkı, egemene karşı görevleri ile genel düzenin sağlanması ve sürdürülmesi konusunda bilgilendirmesini ve eğitmesini sağlamak ile görevli, diğer kamu görevlileri gibi yetkilerini egemenden alan kamu görevlileridir (Hobbes, 2017:185).

Dördüncü sırada yer alan kamu görevlileri ise, kendilerine egemen tarafından yargı yetkisi verilmiş olanlardır. $\mathrm{Bu}$ bakımdan yargı için görevlendirilmiş kamu görevlileri, mahkemelerde egemen adına hüküm vermekte ve

47 Bu yetki genelde, resmi mühürlü yetki yazısı ile verilir. Bu bakımdan resmi mühürlü yetki yazısı, o görevlinin yetkisinin yeterli bir teyidini sağlamaktadır (Hobbes, 2017:207). Öte yandan Hobbes'a göre egemenin buyruğunun icrasında görevli bir kamu görevlisine direnmek suçtur (Hobbes, 2017:226). Hatta Hobbes'a göre bir egemen başka bir egemene teslim olduğunda ve tutsak alındığında bile, monarkın egemenlik hakkını bıraktığı düşünülmemeli ve uyruklar daha önce atanmış olan kamu görevlilerine itaat etmeye devam etmelidir (Hobbes, 2017:172). Egemenin yazılı talimat olmaksızın bir kamu görevlisi istihdam ettiği durumlarda ise görevli, aklının emrettiklerini talimat gibi kullanmak zorundadır. Bu bakımdan Hobbes'a göre görevlinin yazılı talimat yerine kullanması gereken doğal aklı ona, egemene sadık bir şekilde egemen için en uygun olanı yapma yükümlülügünü vermektedir (Hobbes, 2017:205). Diğer taraftan Hobbes'a göre, kamu görevlisi sıfatının sahtecilikle ele geçirilmesi ve kamu mühürlerinin taklit edilmesi de çok büyük bir suçtur (Hobbes, 2017:230).

48 Hobbes'a göre bir insana toplum tarafindan verilen değer, diğer bir deyişle haysiyet; yönetim, yargı ve kamu görevlileri makamları ile bunlarla ilişkili olarak insanlara verilen unvan ve adlardan anlaşılmaktadır (Hobbes, 2017:74). Hobbes'a göre liyakat ise, egemen tarafından kamu görevlisinin seçilmesi sürecinde ilgili kamu görevini iyi bir şekilde yerine getirmeye en uygun veya en yatkın kişinin özel yeteneğidir (Hobbes, 2017:80).

49 Egemen tarafından verilen genel yönetim yetkisi, egemenliğin devredilmesi olarak yorumlanmamalıdır (Hobbes, 2017:185).

50 Hobbes bir ordunun komutanının, ordu içerisinde yeteri kadar popüler olmaması durumunda, görevini başarıyla yerine getiremeyeceğini düşünmektedir. Nitekim ordu mensubu askerlerin, onu (komutanı) sevmesi ve ondan korkması gerekmektedir. Ancak komutanın egemene sadık olması da olmazsa olmaz bir gerekliliktir. Egemene karşı sadık olmayan bir popüler komutan ve askerlerinin varlığı, egemen için tehlikelidir. Bu nedenle egemenin ordu yönetimi için görevlendirdiği komutanın, hem sadık bir uyruk hem de yetenekli bir önder olması oldukça önemlidir (Hobbes, 2017:262). Ayrıca bir orduya kim komutan yapılırsa yapılsın, egemen gücün sahibi daima başkomutandır (Hobbes, 2017:142). 
aslında egemenin kişiliğini temsil etmektedirler (Hobbes, 2017:185). Yarg1 yetkisi egemene (kişi ya da meclis) ait olduğundan bu görevliler, yargı yetkisini egemen güç adına kullanırlar. Dolayısıyla bunlar, egemenin vekilleridir (Hobbes, 2017:185).

Son sırada, icra için görevlendirilen kamu görevlileri vardır. İcra için görevlendirilen kamu görevlileri egemenin verdiği kararların uygulanmasını sağlamak, egemenin emirlerini yayımlamak, kargaşaları bastırmak, barışı sürdürmek gibi konularda hizmet sunan görevlilerdir. Bu bakımdan anılan kamu görevlilerinin görevleri kapsamında egemenden aldıkları yetkiyle yaptıkları şeylere, devletin eylemi olarak muamele edilmektedir (Hobbes, 2017:187).

Hobbes'a göre, egemenin kamusal kişiliği tarafindan yurtdışına gönderilen ve egemeni diğer devletlerde temsil etme görevi verilenler (elçiler, haberciler, temsilciler ve ulaklar) ile yurtdışına bir nevi istihbarat/casusluk hizmeti görmeleri amacıyla gönderilenler ve halkın dilekçelerini kabul edenler de kamu görevlileridir (Hobbes, 2017:187; Güler, 2005:67-68). Hobbes, yalnızca (egemene) görüş bildirme işini yürüten ve yarg1 ya da buyurma yetkisine sahip olmayan danışmanları, kamu görevlisi ve kamusal kişilik olarak saymamaktadır (Hobbes, 2017:187). Bir danışman ya da devlet şurası olarak, egemene, onun tarafından istenildiği zaman görüş bildiren ya da istenilmediği zaman görüş sunan, dolayısıyla egemene hizmet veren bu kişi ya da kişiler egemenin kişiliği karşısında temsil edilemeyeceğinden, ne kamu görevlisidir ne de kamusal kişiliğe sahiptir ${ }^{51}$ (Hobbes, 2017:187).

Özetle Hobbes'un kamu görevlisini (memuru), egemenden yetki alarak ilgili alanda karar alma yetkisine sahip hale gelen ${ }^{52}$ ve yalnızca kamu hizmetlerini yerine getiren uyruklar olarak tanımladığı ifade edilebilir. Bu kapsamda kamu hizmeti ile ilişkili olmayan, ancak yardımcı hizmetleri görenler kamu görevlileri içerisinde sayılmamaktadır (Güler, 2005:66-67).

\subsection{Hareket Ettiriciler: Ödüller ve Cezalar}

Hobbes'a göre egemenlik makamına bağlı yargıçlara, diğer yargı ve yürütme görevlilerine, bir anlamda kamu görevlilerine, egemen tarafından belirlenen sınırlar içerisinde ve onun tarafından verilen yetki ile kendi görevlerini yaptıran ve dolayısıyla devletin organlarını hareket ettiren şey, ödüller ve cezalardır (Hobbes, 2017:17-238-246-264). Genel anlamıyla egemen, önceden yaptığı yasalara uygun şekilde veya bu tarz bir yasa bulunmadığında, uyrukları devlete hizmet etmeye teşvik etmek veya devlete zarar vermekten alıkoymak için uygun göreceği bir şekilde, mal mülk ve şerefle ödüllendirmek veya bedensel/parasal cezalarla ve/veya küçük düşürme yolunu seçerek cezalandırmak hakkına sahiptir (Hobbes, 2017:142-155-260). Ödülleri ve cezaları doğru bir şekilde uygulamak, bir yandan da egemenin görevidir (Hobbes, 2017:259).

Hobbes'a göre ödül, devlete iyi hizmet etmiş olanlar için ya maaş ya da ihsandır (Hobbes, 2017:237-260). Bu bakımdan ödülün bağış ya da sözleşme ile olabileceğini ileri süren Hobbes, sözleşme ile olanın maaş ve ücret adını aldığını ifade etmektedir. Bu anlamda maaş ve ücret, gerçekleştirilen ya da gerçekleştirilmesi vaat edilen hizmetin karşılığıdır (Hobbes, 2017:237). Öte yandan ödülün bağış yolu ile gerçekleştirileni ise uyrukları, kendilerine hizmet etmeye istekli hale getirmek veya hizmet edebilmelerini mümkün kılmak amacıyla, bağışta bulunanların ihsanından kaynaklanan bir faydadır (Hobbes, 2017:237-238).

$\mathrm{Bu}$ bağlamda göre bir egemen bir kamu görevine maaş bağladığında, kamu görevini yerine getiren (kamu) görevli, görevini azami titizlikle yapmaya mecburdur (Hobes, 2017:238). Dolayısıyla kamu görevlisine, kamu hizmetini görmesi ve dolayısıyla özel işlerini bırakmaları için egemen tarafından verilen ödül, maaştır. Hobbes iki türlü maaş olabileceğini belirtmektedir: düzenli ve düzensiz maaşlar (Hobbes, 2017:238). Kamu görevlilerine devlet hazinesinden verilen bazı maaşlar düzenliyken, bazıları belirsiz ve düzensiz olup verilen görevin yapılmasına bağlıdırlar. Bu bakımdan, özellikle yargı alanındaki görevlilere (yargıçlara ve mahkeme görevlilerine) verilen düzensiz maaşların, devletin zararına olabileceğini düşünen Hobbes, bu sakıncalı durumu iki açıdan ele almaktadır. İlk olarak görülen dava sayısına göre anılan görevlilerin maaş alması ilkesi, dava sayısı ile alınan maaş arasında bir doğru orantı içerdiğinden, dava sayısının gereksiz şekilde artmasını

51 Ancak daha önce de belirtildiği üzere, bunlar bir süreliğine de olsa bir kamusal kuruluştur.

52 Kamu görevlileri tarafindan karar alma yetkisi kullanılmayarak gerçekleştirilebilecek bazı hizmetlerin de bulunduğunu kabul etmek gerekir. Örneğin, egemen tarafından icra için görevlendirilen kamu görevlileri, egemenin emirlerini yayımlamak hizmetini yerine getirirken herhangi bir karar alma yetkisini kullanmazken, kargaşaların bastırılması konusunda hizmet görürken anılan yetkiyi kullandığı düşünülebilir. Ancak yine de Hobbes tarafından sayılan kamu görevlilerinin hepsinin en azından bazı konularda karar alma yetkisi ile (egemen tarafından) donatıldığı ifade edilebilir. 
beraberinde getirebilir. İkinci olarak, maaşını arttırmak isteyen anılan görevliler ve dolayısıyla mahkemeler arasında bir rekabet durumu oluşabilir (Hobbes, 2017:238).

Egemenlik makamına bağlı yargıçlara, diğer yargı ve yürütme görevlilerine, bir anlamda kamu görevlilerine, egemen tarafından belirlenen sınırlar içerisinde ve onun tarafından verilen yetki ile kendi görevlerini yaptıran ve dolayısıyla devletin organlarını hareket ettiren şeyler arasında sayılan ceza ise, kamu otoritesinin suç kabul ettiği bir şeyi yapmış insanlara aynı otorite tarafindan kötülük yapılmasıdır (Hobbes, 2017:231). Ceza verilmesindeki amaç, insanların otorite tarafından itaatkâr hale getirilmesidir (Hobbes, 2017:231-259). Uyruklara verilen cezalar ve nitelikleri üzerine detaylı bir açıklama işine girişen Hobbes öncelikle, kamu otoritesinden kaynaklanmayan kişisel kötülüklerin, ceza olarak adlandırılamayacağını belirtmektedir. Ona göre, kamu otoritesi tarafindan bir yargılama yapılmadan ve mahkûmiyet kararı verilmeden yapılan kötülükler de ceza olarak adlandırılamaz (Hobbes, 2017:232-233-259). Ayrıca Hobbes insanların yaptıkları yanlış eylemler sonucunda doğal kötülüğe maruz kalmasını da ceza kapsamına almamaktadır. Nitekim bu kötülükler, beşeri kamu otoritesinden kaynaklanmamakta ve yanlış eyleme doğanın eklediği zararlı sonuçlardan ibarettir (Hobbes, 2017:233). Hobbes'a göre isyan eden uyrukların ya da uyruk olmamakla birlikte yasalara karşı eylemlerde bulunanların kamu otoritesi tarafından kötülüğe maruz bırakılmasının yolu da ceza değil, savaştır (Hobbes, 2017:234). Hobbes'un uyruklar için saydığı bu genel cezalandırma ilkelerinin kamu görevlileri için de geçerli olduğu söylenebilir. Nitekim Hobbes ilgili kısımda, kamu görevlilerinin bu cezalandırma ilkelerinden muaf olduğunu belirtmemektedir.

Diğer taraftan Hobbes cezaları bir sınıflandırmaya da tabi tutmaktadır. İlk ve genel sınıflandırma olarak cezaları ilahi ve beşeri olmak üzere ikiye ayıran Hobbes, insan emriyle (kamu otoritesi tarafından) verilen beşeri cezaları bedensel, parasal, itibarını alma, hapis, sürgün ya da bunların bir karışımı olarak sıralamaktadır (Hobbes, 2017:234). Bunlar arasından her ne kadar yalnızca itibarını alma cezası doğrudan kamu görevlileri ile ilişkilendirilebilecek olsa da, kamu görevlilerinin diğer cezalardan muaf tutulduğu söylenemez. ${ }^{53}$ Diğer bir deyişle kamu görevlisi, yasanın ihlâli durumunda kamu otoritesi tarafından yargılanıp mahkûm edilirse, sıradan bir uyruğa benzer şekilde cezalandırılabilir. Ancak itibarını alma cezasının niteliği gereği kamu görevlileri ile doğrudan bir bağlantısının olduğunu ifade etmek mümkündür. Bu bakımdan itibarını alma cezası, kişiye devlet tarafından aşağılayıcı nitelikteki bir kötülüğün yapılması ya da kişinin yüceltici kılınan bir iyilikten mahrum bırakılması şeklinde gerçekleşmektedir (Hobbes, 2017:235). Devlet tarafından yüceltici kılınmış şeyler arasında sayılan nişanlar, unvanlar ve makamlar gerekli görüldüğü takdirde kamu otoritesi tarafından geri alınabilmektedir. Hobbes'a göre bu geri alma ve kişileri nişanlarından, unvanlarından ve makamlarından yoksun bırakarak aşağılamak ile gelecekte bunlardan mahrum bırakılacaklarını ilan etmek, tam anlamıla bir cezalandırmadır (Hobbes, 2017:235-236).

\subsection{Tavsiye ve Emir Üzerine Bir Kavram Analizi Örneği}

Hobbes'a göre şeylerin doğasına, kelimelerin sıradan ve değişken kullanımına bakarak karar vermek doğru olmamakla birlikte, bu durumun en net örneği emir, tavsiye ve telkin kelimelerinin birbiriyle karıştırılmasıdır ${ }^{54}$ (Hobbes, 2017:193). Her ne kadar bir konuşma içerisinde konuşmayı yapan kişi, konuşmanın yönlendiği kişi ve konuşmanın bağlamı konularında insanların çoğu bir fikre sahip olabilmekte ve bunlar arasında doğru bir ayrım yapabilmekte olsa da, özellikle yazılı olarak anılan kelimeler görüldüğünde insanlar, kimi zaman bağlamı anlayamadıklarından kimi zaman da anlamak istemediklerinden dolayı, çıkarmak istedikleri sonuçlara uygun düşen neyse, anlam olarak onu kabul etme hatasına düşme eğilimindedirler (Hobbes, 2017:193). Bu bağlamda Hobbes'a göre insanlar genelde, tavsiyeleri emirler ya da emirleri tavsiyeler gibi kabul etme hatasına düşmektedirler (Hobbes, 2017:193).

Bu bağlamda Hobbes öncelikle, emir ile tavsiye arasındaki farklara değinmekte ve bu iki kelimeyi birbirinden tamamen ayrıştırmaktadır. Emir, onu verenin iradesinden başka hiçbir şeye dayanmamaktadır. Bu nedenle emir, emir veren kişinin yalnızca kendi çıkarını gözetmekte ve ona (emir verene) bir iyilik sağlamaktadır (Hobbes, 2017:193-194). Diğer taraftan tavsiye, tavsiyeyi veren kişinin değil, tavsiye verilen kişinin çıkarını gözetmekte ve onun (tavsiye verilen) iyiliğini sağlamayı amaçlamaktadır (Hobbes, 2017:194). Dolayısıyla Hobbes’a göre,

53 Kamu görevlilerinin uyruklar için belirlenmiş cezalardan muaf olamayacaklarını söylemek mümkün iken, kamusal kuruluşların bedensel cezalardan doğaları gereği muaf oldukları belirtilebilir (Hobbes, 2017:175).

54 Hobbes "bunu yap" kelimelerinin, emir veren bir kişinin sözcükleri olabileceği gibi, tavsiyede ve hatta telkinde bulunan bir kişinin de sözcükleri olabileceğini belirtmektedir (Hobbes, 2017:193). Hobbes, bunlar arasında bir ayrım yapılabilmesi ve hataya düşülmemesi için, anılan kelimeleri kıyaslama ve tanımlama işine girişmektedir. 
emir ile tavsiye arasında söylenenin kimin çıkarına olduğuna yönelik bir ayrım yapılabilir. Hobbes buradan başka bir ayrımında ortaya çıtı̆̆ııı ifade etmektedir. Buna göre, bir kişi itaat etmeye söz vermiş ise, verilen emire uymak zorunda, ancak tavsiye edilenleri yapmak zorunda değildir (Hobbes, 2017:194).

Öte yandan Hobbes'a göre tavsiye istenen kişi, bu tavsiyenin verildiği kişi tarafından, tavsiyenin niteliği bakımından suçlanamaz ve cezalandırılamaz. Nitekim bir kişiden tavsiye istemek, o kişinin uygun göreceği şekilde tavsiye vermesine izin vermektir. Bu bağlamda egemen (monark ya da meclis) tavsiye istediği kişiyi, kendi düşüncelerine uygun olsun ya da olmasın, tavsiyelerinden ötürü cezalandırma hakkına sahip değildir. Bu bakımdan Hobbes'a göre egemenin yapamadığı bir şeyi, kimse yapamaz ve dolayısıyla tavsiyede bulunan kişiyi suçlayamaz ve cezalandıramaz. Ancak tavsiye, iki uyruk arasında gerçekleşiyor ve bir uyruk diğerine yasalara aykırı nitelikte bir tavsiyede bulunuyorsa, bu tavsiye devlet tarafından cezalandırılabilir. Bu tavsiyenin verilmesinin sebebinin kötü niyet ya da bilgisizlikten gelmesi de bir şey değiştirmez. Nitekim Hobbes'a göre bütün uyruklar, tabi olduğu yasaları öğrenmekle ve bilmekle yükümlüdürler (Hobbes, 2017:194).

Hobbes ayrıca, tenbih ve takbih kelimelerini de bir incelemeye tabi tutmaktadır. Buna göre tenbih, tavsiye veren kişinin, tavsiyeyi alan kişinin bir şeyi yapmasını şiddetli bir şekilde tavsiye etmesidir. Takbih ise bunun karşıtı olarak, tavsiyeyi alan kişinin, bir şeyi yapmaktan caydırılması için verilen şiddetli bir tavsiyedir. Hobbes'a göre dinleyenleri; tavsiyelerinin doğruluğu, saygınlığı ve yararı hakkında ikna amacıyla benzetme, mecaz, misal ve benzeri hitabet araçlarından yararlanılarak yapılan tenbih ya da takbih, tavsiyeden farklı şekilde genellikle onları verenin iyiliğine ve çıkarına yöneliktir (Hobbes, 2017:195). Bu bağlamda tenbih ve takbih, her ne kadar bazı durumlarda tavsiyeyi alan kişinin yararına da olsa, her zaman için onları veren kişilerin yararına olduğu ifade edilebilir (Hobbes, 2017:195). Öte yandan, Hobbes'a göre her ikisi de, yalnızca bir kişi bir topluluğa hitap ettiğinde olabilmektedir. Nitekim tek bir kişiye hitap edildiğinde, hitap edilen kişi sözü kesip hitap eden kişi tarafindan söylenilenleri sorgulayabilmekte iken, hitap edilen bir topluluk aynı sorgulamayı yapma yetisinden uzaktır (Hobbes, 2017:195).

\subsection{Devlet Yönetiminde Tavsiye: Danışmanlık}

Hobbes'a göre egemenin yapması gereken işlerden biri de, devlet yönetiminde tavsiyelerinden yararlanacağı danışmanları seçmektir (Hobbes, 2017:260). Ancak Hobbes, egemenin yalnızca bir monark olduğu durumlarda, danışman seçiminin mümkün ve gerekli olduğunu belirtmektedir (Hobbes, 2017:147-260-261). Bu noktada ehliyetli (iyi) ve ehliyetsiz (kötü) danışmanların farkları üzerinde duran Hobbes, iyi bir danışman olmanın ilk şartı olarak, danışmanlık verenin amaç ve çıkarları ile tavsiyede bulunduğu kişinin amaç ve çıkarları arasında uyumluluk olmas1 gerektiğini belirtmektedir (Hobbes, 2017:196-197).

Hobbes ikinci olarak, iyi bir danışmanın, tavsiye alana gerçeği en açık biçimde (en sağlam muhakemeyle, en anlamlı ve en uygun dille, en özlü biçimde) bildirmesi gerektiğini ifade etmektedir. Nitekim ona göre, üzerine yeterince düşünülmemiş ve muğlak sonuçların tavsiye alan kişiye aktarılması, bir danışmanın görevine aykırıdır. $\mathrm{Bu}$ hususa dikkat edilmemesi durumunda, (kötü) danışman, tavsiyede bulunulan kişiyi yanıltmakta ve başka amaçlara yönlendirmektedir (Hobbes, 2017:197).

Hobbes'un iyi ve kötü danışmanlar arasındaki ayrımda üçüncü olarak saydığı nitelik ise, danışmanın tavsiye verme yeteneğine ilişkin gerekli çalışma ve incelemedir. Ona göre hiç kimse, iyi eğitildiği ve üzerinde çokça kafa yorduğu konular dışında iyi bir danışmanlık hizmeti sunamaz. Bu durum ise iyi bir danışmanın, büyük bir deneyim sahibi olması ile ilgilidir. Hobbes'a göre iyi bir danışman, tavsiye vermesi istenilen konuya ayrıntılarıyla hâkim olmalıdır (Hobbes, 2017:197-198).

Hobbes dördüncü olarak, bir başka devlet ile ilgili bir konuda tavsiye verilmesi özelinde, tavsiye verecek (iyi) danışmanın, o devletten gelen istihbarat ile diğer yazılara ve kendi devleti ile o devlet arasındaki bütün antlaşmalara ve diğer işlemlerin kayıtlarına hâkim olması gerektiğini ifade etmektedir (Hobbes, 2017:198). Hobbes son olarak, danışmanların sayısının eşit olduğu durumlarda, danışmanların topluca değil de ayrı ayrı dinlenilmesinin, tavsiyeyi alan için daha iyi bir yol olduğunu belirtmektedir. Bu bağlamda Hobbes'a göre onları topluca dinlemek, kendi aralarında birbirlerini etkilemelerine ve dolayısıyla, kendi akıllarıyla hareket etmemelerine sebep olabilmektedir. Ayrıca tavsiye istenen konuda danışmanların bazılarının çıkarları, kamunun çıkarları ile çelişebilmektedir. Bu durumda onları topluca dinlemek, çıkarları kamunun çıkarları ile uyumlu olanları da, anılan grubun içerisine çekebilmektedir. Diğer yandan danışmanları topluca dinlemek; bildirilen görüşün nedenlerini, olasılıklarını ve gerçekliklerini incelemeyi ve irdelemeyi de engelleyebilmektedir. Nitekim danışmanlar bire bir dinlendiğinde, tavsiyeyi alan kişi, danışmanlara müdahalede bulunmak ve itiraz etmek yoluyla, bildirimlerin niteliğini ve geçerliliğini sorgulayabilirken; bir kalabalık içerisinde bunu yapmak oldukça 
güçtür. Ayrıca Hobbes'a göre kamu işlerinde, gizlice görüşülmesi gereken fazlaca konu bulunmakta ve bunları, topluca görüşmek devlet için tehlikelidir. Dolayısıyla kamu işlerini ilgilendiren gizli nitelikteki bu konularda, en bilgili ve en sadakatli danışmanlardan oluşan küçük gruplar ile görüşmek, en iyi yoldur (Hobbes, 2017:147-148198-199).

Görevi tavsiyede bulunduğu kişinin yararını gözetmek olan bir danışmanın, tenbih ve takbihe yönelmesi görevinin dışına çıkması demektir (Hobbes, 2017:195). Nitekim kendisinden tavsiye vermesi beklenen, ancak tenbih ve takbih eden danışmanlar, aslında kendi çıkarları doğrultusunda hareket ettiklerinden ötürü, kötü danışmanlardır (Hobbes, 2017:195).

Özetle, ülkenin yönetilmesi konusunda, her biriyle kendi alanlarında ayrı ayrı görüşülen çok sayıda ve ehliyetli (iyi) danışmanların tavsiyeleriyle işleri yürüten kimse, en iyi olanı yapmaktadır. Bu bakımdan Hobbes, kendi alanlarında yeterli donanıma sahip olmayan ehliyetsiz (kötü) danışmanlar ile topluca görüşerek yönetme işine girişen kimsenin, en kötüyü seçtiğini de belirtmektedir. Hatta Hobbes'a göre, tek başına hiç kimseye danışmadan yönetenin seçtiği yöntem bile, bundan daha iyidir (Hobbes, 2017:199). Öte yandan daha önce de belirtildiği üzere, yarg1 veya buyurma yetkisi bulunmayan ve egemen tarafindan istenildiğinde kendisine görüş bildiren, istenilmediğinde görüş sunan danışmanlar, kamusal bir kişiliğe sahip olmamakla birlikte kamu görevlisi sıfatını da taşımamaktadırlar (Hobbes, 2017:187).

Sonuç olarak en yetenekli/ehliyetli/iyi danışmanlar, ${ }^{55}$ verdikleri tavsiyelerde kendi çıkarını gözetmeyen ve devletin barış ve güvenliğine yarayan şeyleri derinlemesine bilen kişilerden seçilmelidir. Ayrıca anılan danışmanlar tavsiyelerini ve nedenlerini egemene (bu durumda monarka) tek tek ve ayrı ayrı sunmalı ve böylece çeşitli duygular (kıskançlık, özenti, korku vb.) nedeniyle verilen tavsiyelerin niteliği egemen için çelişkili ve yanıltic1 hale gelmemelidir (Hobbes, 2017:261-262).

\section{SONUÇ}

Toplumsal Sözleşme Kuramları'nın ilk temsilcisi olan Hobbes'un toplumsal sözleşme ile oluşturulan yapay bir cisim olarak devleti ele aldığı Leviathan eseri, üzerinden yaklaşık dört yüz yıl geçmesine rağmen hala alanda fazlaca çalışılan bir başyapıttır. Eserde Hobbes hem devletin oluşturulmasına hem de işleyişine ilişkin görüşlerini büyük bir tutarlılık içerisinde sunmaktadır. Buna göre devletin var olmadığ 1 doğa durumunda, birbiri ile eşit olan bütün insanlar arasında bitmek bilmeyen bir savaş durumu hâkimdir. Barış şartlarını sunan ve teşvik eden insan aklı ve doğa yasaları ise, herkesin herkese karşı savaş içerisinde olduğu bu durumdan toplumsal sözleşme ile çıkılabileceğini öne sürmektedir.

Hobbes'a göre herkesin doğal hakkını ortaklaşa bir şekilde devretmesine dayanan toplumsal sözleşme yoluyla oluşturulan devletin varoluşsal nedeni, bireylerin güvenliğinin sağlanmasıdır. Devletin var olmadığı doğa durumunda yaşayan insanların güvenlikten yoksun yaşama koşulları ve her insanın doğa durumunda sahip olduğu kendi güvenliğini sağlamak için şiddet kullanabilmesini içeren doğal hak, toplumsal sözleşme ile devredilmekte ve devlet oluşturulmaktadır. Toplumsal sözleşme ile oluşturulan devletin meşruiyeti ise, kendisini oluşturan bireylerin güvenliğini sağlamasından gelmektedir. Hobbes'a göre güvenlik ihtiyacından doğan devlet, eserde açıkça belirttiği üzere güvenliğin sağlanması bakımından tekel bir konuma da sahiptir. Ancak devletin kendisini var eden bireylerin güvenliğini sağlayamaması durumunda, toplumsal sözleşme geçersiz hale gelmekte ve devlet ortadan kalkmaktadır.

Ayrıca dikkat edilirse Hobbes'a göre devlet, yöneten egemen ile yönetilen uyruklar arasındaki bir sözleşmeden değil, uyrukların kendi aralarında gerçekleştirdikleri toplumsal sözleşmeden doğmuş yapay bir cisimdir. Nitekim Hobbes açıkça egemen gücün sözleşmenin tarafı olmadığını eserinde belirtmektedir. Ona göre egemenlik, uyruklar arasında doğa durumunda sahip oldukları doğal hakkın topluca devredilmesi ile gerçekleşen toplumsal sözleşme sonucu hayat bulan devlete, canlılık kazandıran yapay bir ruh gibidir.

Hobbes'a göre mutlak olan egemenliğin kimin tarafından kullanıldığı, devlet biçimlerini belirleyen şeydir. Buna göre egemen güç bir kişi olduğunda monarşi, bir araya gelen herkesten oluşan bir heyet olduğunda demokrasi (halk devleti) ve toplumun sadece bir kesiminin heyeti olduğunda ise aristokrasidir. Hobbes'a göre zor yoluyla kurulmuş bir devletin egemen gücünün sahip olduğu yetki, hak ve sorumluklar ile sözleşme yoluyla kurulmuş bir devletteki egemen gücün sahip olduğu yetki, hak ve sorumluluklar da birbirinin aynısıdır. İki devlet

55 Hobbes’a göre (iyi) danışmanlık, rastgele ya da miras yoluyla da gelmemelidir. Bunun yerine, kamu işlerinde en bilgili olanın danışman olarak seçilmesi gerekmektedir (Hobbes, 2017:261). 
arasındaki tek fark, insanların korktuğu kişinin farklı olmasıdır. Buna göre, sözleşmeyle kurulan devletlerde insanlar birbirinden korktuğu için devleti kurarken, zorla kurulmuş devletlerde insanlar, korktukları kişiye boyun eğmektedirler.

Hobbes eserinde yasa yapma gücünü, yürütme gücünü ve adaletin sağlanması için kullanılan yargı gücünü her ne kadar birbirinden ayrı işlevler olarak ele almış olsa da, yasama-yürütme-yargı erkleri arasında bir ayrıma gitmemektedir. Hobbes'a göre say1lan üç erk de egemen güçte bulunmakta ve hem savaş hem de barış dönemlerinde onun tarafından kullanılmaktadır. Dolayısıyla Hobbes için egemen güç (meclis ya da monark), diğer her şeyin üzerindedir. Hatta bu güç eleştirilemez, suçlanamaz, cezalandırılamaz, devredilemez ve vazgeçilemez niteliktedir. Egemen, hem savaş hem de barış dönemlerinde yasama-yürütme-yargı gücünü tek başına kullandığı gibi; danışmanların, bakanların, yargıçların ve memurların seçimine tek başına karar vermekte, orduya başkomutanlı etmekte, toplum içerisindeki düşünceleri kendisi yönetmekte ve ödüller ile cezaları kendisi belirlemekte ve uygulamaktadır.

Hobbes eserinde bir devletin doğuşundan, biçimden ve gücünden bahsettikten sonra, devletin benzer kısımları olarak adlandırdığı kamusal kuruluşları da ele almaktadır. Dolayısıyla Hobbes devletin kökenine, oluşturulmasına, biçimlerine, gücüne ve varoluşsal nedenine değindikten sonra, artık var olan devletin işleyişine dair konuları da incelemeye tabi tutmaktadır. Bu bağlamda bir konuda veya bir işte bir araya gelen insan sistemleri arasında düzenli, bağımlı ve siyasal olanları kamusal kuruluş olarak niteleyen Hobbes, kamusal kuruluşların kamusal yetki (devletin egemen gücü tarafından verilen sınırlı yetki) ile kurulduğunu belirtmektedir. Dolayısıyla kamusal kuruluşların bağımlı olma özellikleri, onların egemene bağlı ve ona tabi olması ile ilişkilidir. Nitekim Hobbes'a göre düzenli ve siyasal olup bağımlı olmayan insan sistemleri arasında yalnızca devletin kendisi bulunmaktadır. Bu bakımdan egemen gücün karar ve faaliyetlerinin aksine, kamusal kuruluşların karar ve faaliyetleri uyrukların itirazından azade değildir. Hobbes eserinde, kamusal yetki ile kurulan bu kuruluşların çeşitlerinin neredeyse sonsuz sayıda olduğu belirtmektedir. Bunlar arasından bir yerin yönetimi için görevlendirilmiş olanlar, ticaretin düzenlenmesi için görevlendirilmiş olanlar ile egemene yönetimde tavsiye vermek için görevlendirilmiş olanları detaylarıyla inceleyen Hobbes, bunlara ilgili alanda verilen yetkinin sınırsız olmadığını (ki sınırsız yetki yalnızca mutlak egemenliğe sahip olan egemen güçte bulunmaktadır) ve yetkisiz bir şekilde gerçekleştirilen faaliyetlerden kuruluşun temsilcilerinin kamusal olmayan kişiliklerinin sorumlu tutulacağını belirtmektedir.

Bir devletin benzer kısımları olarak adlandırılan kamusal kuruluşları genel hatlarıyla bu şekilde ele alan Hobbes'a göre, devlete hareket kazandıran eklem ve organlar ise kamu görevlileridir. Egemenin verdiği yetki ile faaliyette bulunan kamu görevlileri, toplum indinde haysiyet olarak adlandırılan bir değere sahiptir. Diğer bir deyişle, Hobbes'a göre kamu görevlisi olmak bir haysiyet göstergesidir. Liyakat ise, egemen tarafindan belirli bir alanda devleti temsil yetkisi ile istihdam edilen kamu görevlisinin, kamu hizmetini olması gerektiği gibi yerine getirmesine yardımcı olacak özel yetenekleridir. Bu bakımdan kamu görevlisinin liyakatli olması, egemen tarafından belirlenen sorumluluk alanındaki faaliyetleri gerçekleştirmeye en uygun ve en yatkın kişi olması ile ilişkilidir.

Hobbes'un bir devletin organik kısımları olarak nitelendirdiği kamu görevlilerine, diğer uyrukların itaat etmesi gerekmektedir. Nitekim kamu görevlileri egemenin kamusal kişiliğine hizmet etmek maksadıyla, egemen tarafindan istihdam edilen ve yetkilendirilen kişilerdir. Bu bakımdan kamu görevlilerinin egemenin buyrukları ve yasaları ile uyumlu faaliyetleri, uyruklar için eleştirilmesi dahi mümkün olmayan egemenin faaliyetlerinden farksızdır. Ancak belirli bir alanda devletin kişiliğini temsil etmesi için egemen tarafından görevlendirilen ve yetkilendirilen kamu görevlileri üzerinden o alanda egemenliğin devredildiği/terkedildiği anlamının çıkarılmaması gerekmektedir. Nitekim kamu görevlileri egemenin iradesine dayanmayan hiçbir hakka sahip değildir. Kamu görevlilerinin görevlendirildikleri alanlara göre sınıflandırmasının da yapıldığı eserde, her bir kamu görevlisi sınıfının en azından bazı konularda karar verme yetkisi ile donatıldığı da belirtilmektedir.

Eserde her eklem ve organa, bu durumda kamu görevlilerine, egemenin verdiği yetki ve sınırlar dâhilinde kamu hizmetini gördüren şey olarak sunulan mekanizma ise, bir vücuttaki sinirlere benzetilen ödüller ve cezalardır. $\mathrm{Bu}$ çerçevede egemenin ödüller ve cezalara karar vermesi ve uygulaması, onun hem yetkisi hem de sorumluluğu ve görevidir. Kamu görevlileri, uyrukların tümü için geçerli olan ve kamu otoritesi olan egemen tarafindan belirlenen ödüller ve cezalardan azade olmamakla birlikte, kendilerine has bir takım ödüller ve cezalar bağlamında da ele alınmaktadır. Buna göre devlete kamunun yönetiminde hizmet sunan görevliler, devletin hazinesinden sözleşmeye dayalı bir şekilde düzenli veya düzensiz bir maaşa bağlanarak ödüllendirilmektedirler. Bu kapsamda Leviathan eserinde Hobbes, düzenli maaşların kamu görevlisine iş gördürmek bağlamında daha doğru bir uygulama olduğunu savunmaktadır. 
Kamu görevlileri arasında saydığ 1 yargıçlar üzerinden verdiği örnekte Hobbes, düzensiz maaşların kamu hizmetinin görülmesinde bir anlamda rekabeti de beraberinde getirdiğini ve bu durumun amaca çok da uygun düşmediğini belirtmektedir. Diğer yandan Hobbes'a göre maaş, kamu görevlisi olarak seçilen uyrukların özel işlerini tamamen bırakarak yalnızca kendilerine verilen kamu hizmetini görmelerini sağlamak bakımından olmazsa olmaz bir ödüldür. Bir diğer deyişle kamu görevlisine verilen maaş, seçilen uyrukların hizmet edebilmelerini mümkün kılmaktadır. Hobbes'a göre bir uyruğa kamu görevlisi olması bakımında maaş bağlandığında o uyruk, istihdam edildiği alandaki kamu hizmetini azami titizlikle yerine getirmeye mecburdur. Hobbes'a göre kamu görevlilerini harekete geçirme işlevi de bulunan cezalar ise, kamu otoritesinden kaynaklanmakta ve onun tarafından suç teşkil ettiğine bir yargılama sonucu kanaat getirilen konularda ilgili uyruğa itaatkâr hale gelmesi amacıyla kötülük yapılmasıdır. Kamu otoritesi tarafından verilen cezaları bedensel, parasal, itibarını alma, hapis, sürgün ya da bunların bir karışımı olarak sıralayan Hobbes, bunlar arasından itibarını alma cezasını doğrudan kamu görevlisine ilişkin bir ceza türü olarak incelemektedir. Bu çerçevede kişiyi, toplum indinde bir haysiyet göstergesi olan kamu görevlisi olma sıfatından mahrum etmek ve anılan sıfatı geri almak ile gelecekte de anılan sıfata sahip olunamayacağını açıklamak, tam anlamıyla bir cezalandırmadır.

Öte yandan Hobbes'un emir ve tavsiye sözcüklerinin anlamlarının birbirinden net bir şekilde ayrıştırılmasına ayırdığı eserinin ilgili bölümü, devlet yönetiminde tavsiye ve danışmanlık olgusuna ilişkin doyurucu bir kılavuz niteliğindedir. Hobbes'a göre emir, onu verenin iradesinden başka hiçbir şeye dayanmamaktadır. Bu çerçevede emir, onu verenin çıkarına ve iyiliğine yöneliktir. Diğer taraftan tavsiye, tavsiyeyi veren kişinin değil, tavsiye verilen kişinin çıkarını gözetmekte ve onun (tavsiye verilenin) iyiliğini sağlamayı amaçlamaktadır. Dolayısıyla Hobbes, emir ile tavsiye arasında söylenenin kimin çıkarına olduğuna dayanarak bir ayrım yapmaktadır. Ayrıca bir kişi itaat etmeye söz vermiş ise verilen emire uymak zorunda, ancak tavsiye edilenleri yapmak zorunda değildir. Hobbes'a göre tavsiye vermesi için başvurulan kişi, tavsiyeyi isteyen kişi tarafından tavsiyenin niteliği bakımından suçlanamaz ve cezalandırılamaz. Nitekim bir kişiden tavsiye istemek, o kişinin uygun göreceği şekilde tavsiye vermesine izin vermektir.

Bu bağlamda egemen, devlet yönetimine dair tavsiye vermesini istediği kişiyi, kendi düşüncelerine uygun olsun ya da olmasın, tavsiyelerinden ötürü cezalandırma hakkına sahip değildir. Diğer yandan Hobbes'a göre egemenin devlet yönetimindeki sorumluluklarından biri de, tavsiyelerinden yararlanacağı (iyi/ehliyetli) danışmanları seçmektir. Egemen bu seçimi yaparken tavsiye yerine tenbih, takbih, telkine yönelen ve kendi çıkarını ön planda tutan danışmanları tercih etmemelidir. Hobbes'a göre egemenin tavsiye alacağı iyi ve ehliyetli danışmanlar; amaç ve çıkarları bakımdan egemenin amaç ve çıkarları ile uyumlu, en sağlam muhakeme yeteneğine sahip, tavsiye istenilen alanda eğitimli ve deneyimli olanlar arasından seçilmelidir. Nitekim Hobbes'a göre egemenin kötü ve ehliyetsiz danışmanlardan tavsiye alması yerine, hiç kimseden tavsiye almadan devleti yönetmesi daha iyi bir seçenektir.

Seçilen iyi ve ehliyetli danışmanların egemen tarafından ayrı ayrı dinlenilmesinin egemene devlet yönetiminde sağlayacağı faydanın, onların topluca dinlenilmesine kıyasla çok daha büyük olduğunu belirten Hobbes, danışmanların birer kamu görevlisi olmadığını da ifade etmektedir. Tavsiye sözcüğünün niteliği bakımından görevi egemene, onun tarafından istenildiği zaman görüş bildirmek ya da istenilmediği zaman görüş sunmak olan danışmanlar, egemenin kişiliği karşısında temsil edilemeyeceğinden Hobbes'a göre ne kamu görevlisidir ne de kamusal kişiliğe sahiptir. Ayrıca Hobbes'a göre danışmanların, yargı ve/veya buyurma (emir) yetkisi bulunmaktadır. Ancak Hobbes danışmanlardan oluşan ve görevi egemene tavsiye vermek olan düzenli, bağımlı ve siyasal insan sistemlerini, kamusal kuruluşlar arasında saymaktadır.

Sonuç olarak Hobbes Leviathan'da, hem devletin var oluşuna ve kökenine ilişkin detaylı açıklamalar sunmakta, hem de bireylerin güvenliğinin sağlanması amacıyla var edilen ve meşruiyetini güvenlik ihtiyacını karşılamak için gerçekleştirilen toplumsal sözleşmeden alan devletin yönetimine ilişkin çeşitli kuruluş, işleyiş ve mekanizmaları incelemektedir. Bu nedenle eser Siyaset Bilimi alanında bir başyapıt olmasının yanı sıra, Yönetim Bilimi alanında da incelenmesi gereken temel eserler arasında kendisine yer bulmaktadır. Ancak alan yazında, eserin daha çok Siyaset Bilimi’nin kapsamına giren kısımları üzerine çalışma yapıldığı, kamunun yönetimine ilişkin kuruluş, işleyiş̧ ve mekanizmaları açıklayan kısımlarının ise genelde derinlemesine incelenmediği ifade edilebilir. Bu bakımdan yapılan çalışma ile hem devletin oluşturulmasına ilişkin eserdeki kavram ve kabullerin, hem de bir kere oluşturulduktan sonra yönetime dair kuruluş, işleyiş ve mekanizmaların genel hatlarıyla ortaya konulması amaçlanmıştır. 


\section{KAYNAKÇA}

AĞAOĞULLARI, Mehmet Ali ve AKAL, Cemal Bâli ve KÖKER, Levent (1994), Kral Devlet ya da Ölümlü Tanrı, İmge Kitabevi, Ankara.

AUBREY, John (1982), Brief Lives, The Boydell Press, England.

BEKTAŞ, Arsev (1993), “Machiavelli ve Hobbes: 'Siyasal İktidar' ve 'Güç' Analizleri”, Marmara İletişim Dergisi, S.3, ss.177-188.

CAMBRIDGE DICTIONARY (1999), "Province", E-Dictionary, Cambridge Dictionary Press, https://dictionary.cambridge.org/dictionary/english-/province, (Erişim Tarihi: 11.02.2020).

CEVİĊ, Ahmet (2013), On Yedinci Yüzyıl Felsefesi, Say Yayınları, İstanbul, 3. Baskı.

ÇAPAR, Selim ve YILDIRIM, Şükrü (2012), “Hobbes ve Locke'un Devlet Düşüncesine Katklları”, Türk İdare Dergisi, S.474, ss.77-102.

DUNCAN, Stewart (2019), "Thomas Hobbes", The Stanford Encyclopedia of Philosophy (Ed. Edward N. Zalta), Standford University Press, Standford, https://plato.stanford.edu/archives/spr2019/entries/hobbes/, (Erişim Tarihi: 11.02.2020).

ENCYCLOPAEDIA BRITANNICA (?Tarihsiz), "Restoration”, E-Encyclopaedia, Encyclopaedia Britannica Inc., https://www.britannica.com/topic/Restoratio-n-English-history-1660, (Erişim Tarihi: 11.02.2020).

GOLDSTEIN, Daniel M. (2010), "Toward a Vritical Anthropology of Security", Journal of Current Anthropology, S.51(4), ss.487-517.

GÖKBERK, Macit (1985), Felsefe Tarihi, Remzi Kitabevi, İstanbul, 5. Bask1.

GÜLER, Birgül Ayman (2005), Kamu Personeli: Sistem ve Yönetim, İmge Kitabevi, Ankara.

GÜRİZ, Adnan (1955), "Hobbes, Şansiyeti ve Siyasî Fikirleri”, Ankara Üniversitesi Hukuk Fakültesi Dergisi, S.12(1), ss.298-315.

HEYWOOD, Andrew (2015), Siyasetin Temel Kavramları (Çev. Hayrettin Özler), Adres Yayınları, Ankara, 2.Bask1.

HILL, Christopher (2016), İngiltere'de Devrim Çağı: 1603-1714 (Çev. Uygur Kocabaşoğlu), İletişim Yayınları, İstanbul.

HOBBES, Thomas (2017), Leviathan veya Bir Din ve Dünya Devletinin İçeriği, Biçimi ve Kudreti (Çev. Semih Lim), Yapı Kredi Yayınları, İstanbul, 15.Baskı.

KÖSSLER, Reinhart (2003), "The Modern Nation State and Regimes of Violence: Reflections on the Current Situation", Ritsumeikan Annual Review of International Studies, S.2, ss.15-36.

MALCOLM, Noel (2012), The Clarendon Edition of the Works of Thomas Hobbes, Vol. 3: Leviathan: Editorial Introduction, Oxford Scholarly Editions Online, Oxford.

MALCOLM, Noel (2006), "A Summary Biography of Hobbes", The Cambridge Companion to Hobbes (Ed. Tom Sorell), Cambridge University Press / Cambridge Companions Online, Cambridge, ss.13-44.

MARTINICH, Aloysius P. (2013), Hobbes (Çev. Akın Terzi), Türkiye İş Bankası Kültür Yayınları, İstanbul.

PIERSON, Christopher (2004), The Modern State, Routledge Press, USA.

POGGI, Gianfranco (2016), Devlet Doğası, Gelişimi ve Geleceği (Çev. Aysun Babacan), İstanbul Bilgi Üniversitesi Yayınları, İstanbul, 5.Bask1.

RYAN, Alan (2013), On Politics: A History of Political Thought from Herodotus to the Present, Allan Lane Press, London.

SPEAKOLA (2017), "crmwell", Speakola Social Platform, https://speakola.com/political/oliver-cromwellspeech-dismissing-rump-parli-ament-1653, (Erişim Tarihi: 31.12.2019).

TANNENBAUM, Donald G. ve SCHULTZ, David (2006), Siyasî Düşünce Tarihi: Filozoflar ve Fikirleri (Çev. Fatih Demirci), Adres Yayınları, Ankara. 
TUCK, Richard (2016), Hobbes (Çev. Nursu Örge), Dost Kitabevi, Ankara.

WIESNER-HANKS, Merry E. (2009), Erken Modern Dönemde Avrupa: 1450-1789 (Çev. Hamit Çalışkan), Türkiye İş Bankası Kültür Yayınları, İstanbul.

WIMMER, Hannes (2003), "The State's Monopoly on Legitimate Violence”, Transformations of Statehood from a European Perspective, Paper for the Conference, Vienna (Austrian Academy of Sciences), ss.136.

ZABUNOĞLU, Yahya Kazım (1959), "Thomas Hobbes, Hayat,, Eserleri ve Hukukî Fikirleri”, Ankara Üniversitesi Hukuk Fakültesi Dergisi, S.15(1), ss.219-240. 